\title{
Optic nerve axons: life and death before birth
}

\begin{abstract}
In the 2004 Bowman Lecture, I give a panegyric for Sir William Bowman, an estimate of the importance and the epidemiology of anterior visual pathway developmental disorders, followed by a history of the anterior visual system. I review the normal development of the optic nerve and chiasm and the main developmental disorders: Optic Nerve Aplasia, Optic Nerve Hypoplasia and Achiasmia.

Eye (2005) 19, 499-527. doi:10.1038/sj.eye.6701857

Published online 1 April 2005
\end{abstract}

Keywords: optic nerve development; optic nerve hypoplasia; optic nerve aplasia; Achiasmia; optic nerve; septo-optic dysplasia

\section{Bowman: the great Clinician-Scientist}

Henry Power wrote a 'Prefatory Memoir' to the two volumes of collected Papers of Sir William Bowman, published in the year of his death, which described his life and times. ${ }^{1}$ William Bowman, his father a botanist and geologist who worked as a banker, his mother a draftswoman and painter of flowers, was born in Nantwich on 20 July 1816. He married Harriet Padget in 1842 and they had seven children; his family life was especially precious to him. He regularly attended church at St James, Piccadilly, when he was in London (Figure 1) and at the church in the village of his country house, Joldwynds, Holmbury St Mary, near Dorking, Surrey. He died aged 76 on 29 March 1892; he is buried in the churchyard there.

He was educated at the Hazelwood School in Birmingham from the age of 10 and, after a period in a country practice, was apprenticed to a locally renowned surgeon, Mr Joseph Hodgson, aged 16 in 1832. In 1837 he moved to Kings College, London where he held various
D Taylor ${ }^{1,2}$

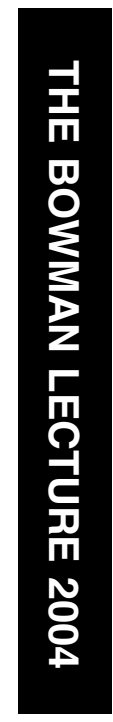

positions, as Prosector and Demonstrator, under John Simon and then Robert Bentley Todd. He was made Fellow of the Royal College of Surgeons in1840; resigning from the hospital a few years later because of pressures in his practice but he was still an active Council member and Chairman of the Medical Committee of Kings College Hospital at the time of his death. He had an appointment at the Royal London Ophthalmic Hospital between 1846 and 1876.

His early scientific work, much of which was published jointly with Robert Bentley Todd (1809-1860) in The Physiological Anatomy and Physiology of Man, ${ }^{2}$ accurately showed microscopic anatomy and related structure to function in muscle, kidney, the cochlea, skin, and other organs; he was greatly helped by his inherited drawing skills. Todd and Bowman's views on anatomy and physiology of the optic nerve (ON) were, naturally, coloured by the viewpoints of their teachers: 'Their (the optic nerves) anatomical disposition 'place it beyond all question that they are the proper conductors of visual impressions to the sensorium' and ' from this chiasma, the optic nerves spring, and diverge as they pass forwards into the orbits through the optic foramina'. Todd and Bowman offered an explanation for the blind spot which had been surprisingly difficult to grasp: 'If the blind spot had been situated in the axis, a blank space would have always existed in the centre of the field of vision, since the axes of the eyes, in vision, are made to correspond. But ... the blind spots do not correspond when the eyes are directed to the same object, and hence the blank, which one eye would present, is filled up by the opposite one'.2

Bowman must have been one of the first to view the $\mathrm{ON}$ with an ophthalmoscope after its invention by Helmholtz in 1851, but his apparently expert use of this revolutionary instrument never resulted in publications on the $\mathrm{ON}$, probably because his manual dexterity and the pressures and needs of practice led him to
${ }^{1}$ Institute of Child Health, London WC1N IEH, UK

${ }^{2}$ Great Ormond Street Hospital, London WC1N 3JH, UK

Correspondence: D Taylor E-mail: d.taylor@ ich.ucl.ac.uk

Received: 20 July 2004 Accepted: 20 July 2004 Published online: 1 April 2005 


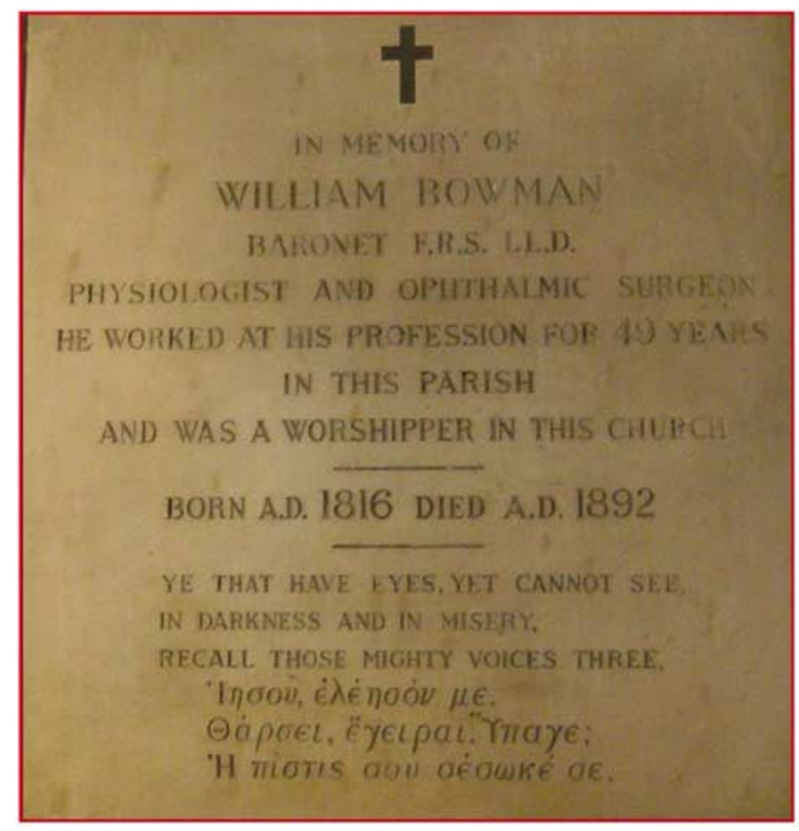

Figure 1 The text of a plaque in St James' Piccadilly where Bowman worshipped when in London. The biblical quotes in Greek are: 'Jesus have mercy on me'. 'Be brave, rise and go'. 'Your faith has saved you'.

more surgical fields. Also in 1851 he met Albrecht von Graefe and Donders who had come to London to view the Great Exhibition, resulting in a friendship that lasted to their death. Eduard Jaeger ${ }^{3}$ and von Graefe ${ }^{4}$ were struggling to fit their ophthalmoscopic findings to their framework of diseases (see below).

Bowman was the first President of the Ophthalmological Society of the United Kingdom, the predecessor of the now Royal College of Ophthalmologists. He was admitted as a Fellow of the Royal Society in 1841.

He retired from the Royal London Ophthalmic Hospital in 1876 by reason of his age, but remained preeminent in private practice. 'In consultation he was gentle, patient, and thoughtful; alive to, and quickly seizing, the salient points of every case; very reserved, giving his opinion in a few words, both as to forecast and treatment'.

In an address to the Medical Students ${ }^{1}$ and others at Kings College Medical School, he encouraged them to work ceaselessly, especially in the dissecting room, the lecture room, the Library and particularly at the bedside, creating case records (illustrated if they were able to do so) and to look after their own health, making best use of what little leisure time they had. 'Seek less to derive honour from your profession, than to honour your profession by your virtues'.
Bowman communicated an early study by the famous anatomist Henry Gray on chick micro-embryology, to the Royal Society in 1850 . He was one of the first to recognize that the eye was not just intimately attached to but originated from the brain. 'From the circumstance of the retina arising, as it undoubtedly does, from the cerebral cells being in fact a part of them and performing a similar function, we have, I think, a great proof of the similarity in the structure of these two parts'. Gray traced some of the developing $\mathrm{ON}$ to the thalamus, not previously recognized. It is important to realize that his name is not just revered in Ophthalmology and such was the ambience of Bowman's scientific life that, in addition to his busy practice, he was a part of the buzzing biosciences scene that was England 150 years ago.

\section{The importance of developmental disorders of the anterior visual pathways}

It is difficult to find out why there are so few reports of developmental abnormalities such as Optic Nerve Hypoplasia $(\mathrm{ONH})$ in the early literature: is it because it was much more rare than today or was it simply not recognized? The former is a possibility, but it seems unlikely that there is an enormous difference in incidence in view of what we know about the pathogenesis of $\mathrm{ONH}$ and the latter seems unlikely in view of the great expertise of the early ophthalmoscopists, following the invention of the ophthalmoscope in 1851.

But 'you see what you know': remember that two giants of ophthalmology, Eduard Jaeger ${ }^{3}$ and Albrecht von Graefe, ${ }^{4}$ in the early years of ophthalmoscopy, both perceived the glaucomatous $\mathrm{ON}$ to be swollen, not cupped. They presumably did this, as they learned to use the ophthalmoscope, by expecting a swollen (inflamed) disc and misinterpreting the effect of parallax.

Some of the early fundus drawings ${ }^{5,6}$ could be interpreted as showing mild $\mathrm{ONH}$ but why were there no early recorded cases of severe $\mathrm{ONH}$ (Figure 2) when optic nerve aplasia (ONA) had been described in 1864 ? $^{7}$ The paucity of early reports ${ }^{8-16}$ suggested that $\mathrm{ONH}$ was a very rarely diagnosed congenital anomaly, but nowadays paediatric ophthalmologists in hospital practice see several new cases each year and it is a significant cause of blindness in childhood, possibly with an increasing incidence. ${ }^{17,18}$ The truth probably lies in the middle: it is more common and better recognized. $\mathrm{ONH}$ is now probably the most common optic disc anomaly. ${ }^{19}$

Estimates of the prevalence have suggested that $\mathrm{ONH}$ occurs in 1.8-6.3 per 100000 births, ${ }^{18,20}$ a more recent study $^{21}$ from Sweden suggested around 7 per 100000 births. At least four of every 10000 children born in the UK will be diagnosed as severely visually impaired or blind (SVI/BL) by their first birthday, increasing to 


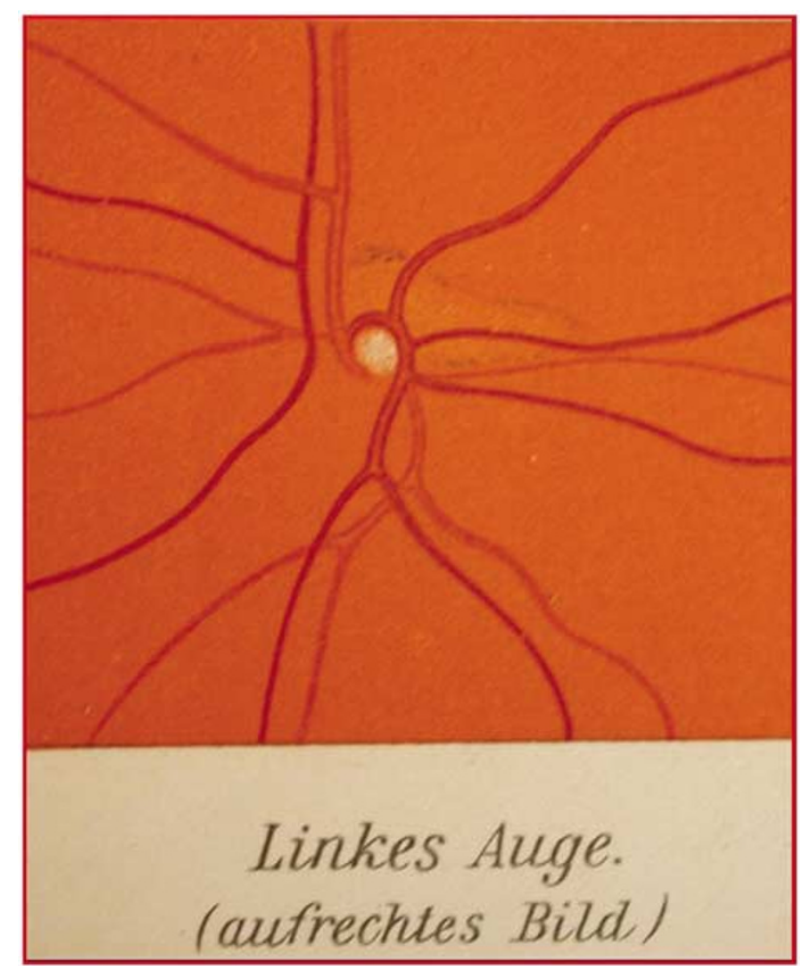

Figure 2 Early illustrations of $\mathrm{ONH}$ are few and suggest that the incidence might be lower than today. This may reflect an increased incidence or more frequent diagnosis, probably both In view of the skill of early ophthalmoscopists, it seems that it was not an inability to see the hypoplasia, but to recognize it. This is an illustration in an article by Schwartz. ${ }^{16}$

nearly six per 10000 by the age of 16 years. ${ }^{22}$ Abnormalities of the ON were a cause of SVI/BL in $28 \%$ of children in a nationwide surveillance in the UK. ${ }^{22}$ $\mathrm{ONH}$, either isolated or as a part of septo-optic dysplasia accounts for $12 \%$ of the total. In all, $10 \%$ of the 439 children with all diagnoses reported to the study died within 1 year of diagnosis, $77 \%$ in the first year of life, giving an infant mortality in SVI/BL of 119.3 per 1000 .

The abnormalities are not just important because of their being a cause of lifelong blindness, with its global effects on life, education, family dynamics, social life, and employment. As developmental abnormalities of the anterior visual pathways are often associated with brain, endocrine, and other problems, they may have far greater significance.

\section{The anterior visual system in history}

This history is an abbreviated version of the paper ${ }^{23}$ by the medical historian, Dr Carole Reeves and I, which we read at the Cambridge Ophthalmological Symposium in 2003: I warmly recommend the interested reader to this article which is mostly the work of Dr Reeves.
From $c .300 \mathrm{BC}$ to the early 19th century, the most consistent theory of nerve function involved a pneuma or spirit travelling through a hollow nerve. Galen (129-c. 216 BC) wrote about nerve 'channels' which were described by Herophilus (c. 330-260 BC) and Erasistratus (c. 330$255 \mathrm{BC}$ ), the first documented human anatomists. Galen's theory passed into the Arab-Islamic world: one of the most important writers was Hunain ibn Ishaq (c. 809-c. 873), whose book of the Ten Treatises on the Eye was the chief source for medieval ophthalmologists in the West.

A 1000 years after Galen, William of Conches maintained a humorist interpretation of vision. 'Spiritual virtue', from the heart, passed through 'thin vessels' to the brain where it was further refined into psychic pneuma by the rete mirabile, the network of nerves and vessels which Galen had found and believed existed in humans. ${ }^{24}$ It then travelled through hollow nerves to the organs of sense. When the soul wished to see, it sent pneuma through the ONs to the eye which emerged through the pupil, mingling with the external light and extending to the object. Having diffused over the surface of the object, it returned to the soul carrying the visual impression. As proof of this physiological process, William cited the fact that the eye of an observer might itself be corrupted by looking at a diseased eye since the blight would be carried back on the psychic pneuma - the 'evil eye'.

Andreas Vesalius (1514-1564) was among the first to doubt the hollowness of the ON, having searched for it in dogs, larger animals, and in a man just beheaded. ${ }^{25}$ Nevertheless, so strong was Galen's hold on anatomy that Vesalius did not deny the hollowness of nerves. The Dutch draper and early microscopist, Antoni van Leeuwenhoek (1632-1723), proposed a mechanical theory of vision and Isaac Newton's (1642-1727) mechanical model of nerve action, using the 'vibrating motion' of an aetherial medium, had no need for a hollow nerve.

Albrecht von Haller (1708-1777), the outstanding Swiss physiologist, postulated a vis nervosa or a force originating from the brain which resided in the nerves The idea of a vis nervosa being electrical in nature, although rejected by Haller, was popularized following the invention of the Leyden jar, and through investigations of electric fish by John Hunter, Henry Cavendish, Alexander von Humboldt, and Humphry Davy. Galvani's proposal, in 1791, that the nervous system generated electricity swept away the humoral theories of nerve action: they had lasted 2000 years - and still linger in some quarters! Emil du Bois-Reymond (1818-1896) showed conclusively that electrical currents were present in nerves; his student, Ludimar Hermann (1838-1914), first demonstrated that nerves gave rise to a self-propagating wave of negativity which advanced in 
segments, although he was unable to explain how it was transmitted from segment to segment. But it was not until the 20th century that Edgar Adrian (1889-1977) and his team revealed that the conduction signal resulted from the transfer of ions across the membrane of a nerve fibre which sent a wave of depolarization or action potential along the axon.

The revolutionary introduction of the ophthalmoscope by Helmholtz in 1851 made it necessary for ophthalmologists to perceive and interpret what they saw through the instrument; it enabled the clinician to differentiate between 'sensorial' blindness which had its seat in the retina, $\mathrm{ON}$ or optic tubercle (disc), and those 'large numbers of cases of amaurosis' which originated not in the eye but elsewhere; it threw over old diagnoses and enabled a whole new classification of disease of the anterior visual system including the ones we are interested in here.

When we get to the chiasm, the earliest reference to decussation ${ }^{26}$ was by Albert the Great (1197-1280) who, on clinical grounds alone, postulated the crossing of some fibres in the chiasm. John 'Chevalier' Taylor, better known in his role as a charlatan and itinerant surgical quack in the 18th century, was another advocate of partial decussation: ${ }^{27,28}$ In many ways Chevalier Taylor was an admirable philosopher and doctor: it seems bad luck that human nature is such that we remember, selectively, the least complimentary aspects of someone's life!

\section{The normal development of the anterior visual pathway}

\section{Retinal ganglion cell axons (RGC)}

Progenitor cells - the emergence of ganglion cells In embryonic development, the vastly different neuronal types that become the structure of the mature neuroretina derive from a population of multipotent retinal progenitor cells. Retinogenesis proceeds in a chronological order, with the principal cell classes generated in successive phases. RGC are the first to develop, Müller cells the last. After embryonic development, in fish and amphibians, new cells can be added from the periphery of the retina, the ciliary marginal zone ${ }^{29}$ and similar pluripotential cells have been identified in mammals ${ }^{30}$ with interesting but unrealized possibilities for retinal regeneration ${ }^{31}$ in mature mammals.

\section{Cell signalling, axonal guidance in the retina and $\mathrm{ON}^{32}$} As RGC axons sprout, they find their way to the foetal fissure, optic stalk and later to the $\mathrm{ON}$ in an almost unerring fashion, guided by the motile tip of the axon,

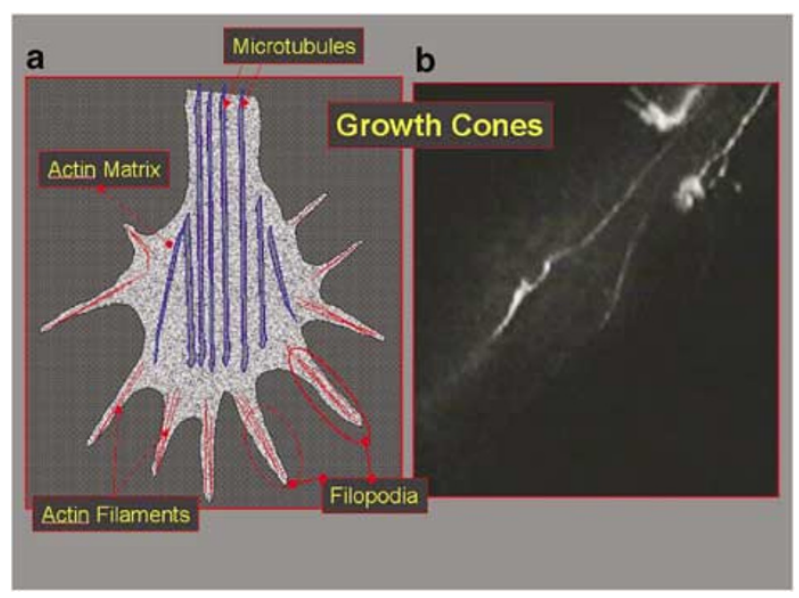

Figure 3 (a) Diagram of a growth cone. Growth cones form the tips of growing axons: they are vital to the enormously complex task of guiding the axon to its target cell, which may be at a considerable distance from the neuron's cell body. Filopodia, which protrude from the tip of the cone and retract from the trailing edge (movements enabled by actin filaments), grow out of the body of the cone. (b) Growth cones responding to guidance cues can be viewed at:- http://www.ucsf.edu/ neurosc/faculty/Sretavan/Eph-timelapse.html (illustration by courtesy of Dr David Sretavan).

the growth cones (Figure 3), which respond to various cues in their environment. The filopodia which emanate from the growth cones respond to arrays of growthpromoting and -inhibiting guidance cues and 'steer' developing axons along specific pathways to their targets $^{32-34}$ by attraction or repulsion. Some attractants can become repellents when they have had contact with the axon they have attracted - thus sending it onwards. The cellular mechanisms by which steering takes place, once mysterious, are becoming more clear; ${ }^{35,36}$ the growth cone changes molecularly as it progresses toward its target, and it changes with age. Multiple guidance cues trigger localized degradation, synthesis, or downregulation of proteins in the growth cone which alter its direction of travel, ${ }^{35}$ steering it towards or away from the cue on its marathon journey to its target (Figure 4).

\section{Attractants}

Some of the molecules that promote growth include fibronectin glycoproteins and the laminin family of polypeptides. The first-born ganglion cells appear around the area of the future optic disc, later more peripherally. Their axons of the newer RGCs form bundles ('fascicles') under the influence of attractant adhesion molecules such as L1, and they are attracted to the foetal fissure or optic disc by attractant guidance molecules around the disc such as Netrin- $1:^{37,38}$ deletion of the netrin-1 gene in mice results in $\mathrm{ONH}^{37}$ 


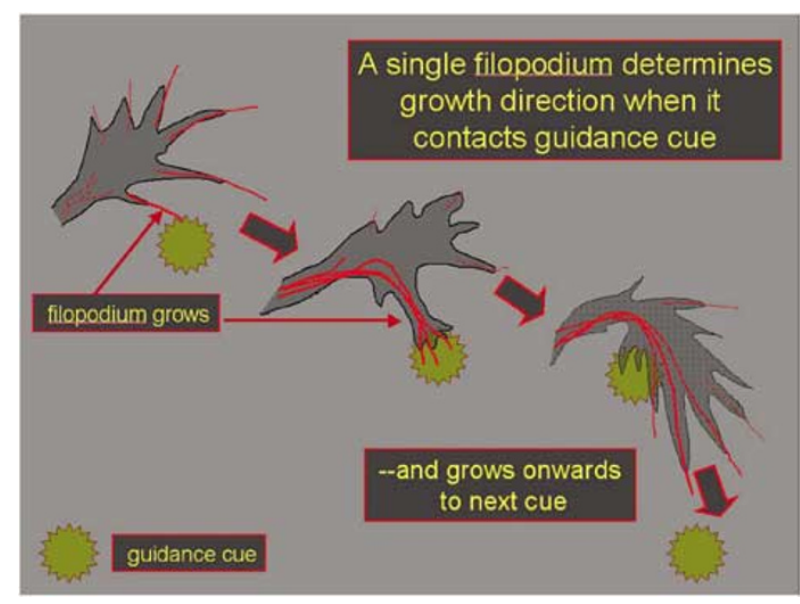

Figure 4 Filopodia have receptors sensitive to guidance cues in the surrounding medium on their surface. The filopodium influenced by the guidance cue enlarges in the direction of the cue, guiding the cone to the cue by a number of mechanisms. ${ }^{35}$

Inhibitors and repellents

RGC axons heading to the optic disc may encounter a gradient of inhibitory EphB proteins, which helps maintain tight axon fasciculation and prevents aberrant axon growth into the ventral retina. ${ }^{39}$ Retinal axons tended to avoid EphB-extracellular domains (ECDs), and exposure to soluble EphB-ECDs led to growth cone collapse or other inhibitory responses. Mice lacking both EphB2 and EphB3 receptor tyrosine kinases ${ }^{40}$ exhibit increased frequency of RGC axon guidance errors.

Semaphorins (Sema) are a family of diffusible proteins, some of which act as inhibitory guidance molecules at a distance from the developing axon. ${ }^{41,42}$ Sema3A is involved in the axon guidance of cranial nerves and invertebrate RGCs. Growth cone responses to a specific guidance molecule can be altered by exposure to a second guidance molecule: in mouse, Sema5A triggers ${ }^{43}$ an inhibitory response when exposed to L1, laminin, or netrin-1 signalling, suggesting that it inhibits retinal axons in the optic disc and nerve. In rat ON explants, Sema5A, expressed by ON glial cells (oligodendrocytes in particular), induces collapse of RGC growth cones, inhibiting (repelling) axon re-growth: if this effect is blocked, axon growth is significantly increased. ${ }^{44}$

On a wider and more sophisticated scale, gradients of inhibitory or repellent molecules, for instance, ephrins, ${ }^{45}$ guide RGC axons to generate a retinotopic map in the colliculus or the lateral geniculate body.

\section{Integrated and concerted action}

The guidance molecules work in concert, overlapping and integrating: RGCs are repelled from the retinal periphery by Chondroitin sulphate, fasciculated by L1 and follow an Ephrin gradient, attracted to the disc by Netrin-1. In some circumstances reverse signalling

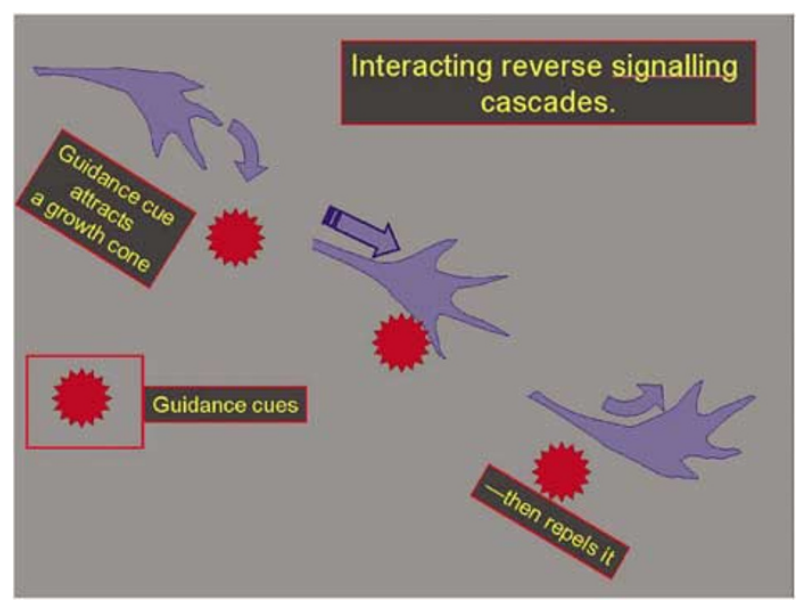

Figure 5 Guidance cues (see text) may attract some growth cones and repel others. Some guidance cues may switch from being attractive to repulsive.

occurs - molecules can have effects that are opposite to their normal ones: ${ }^{39,40}$ Netrin-1, for instance, can turn from a chemo-attractant to a chemo-repellent in the presence of cytosolic cAMP ${ }^{46}$ (Figure 5). EphB triggers growth cone collapse in the presence of laminin, but when co-stimulated with L1 a pause in growth occurs without collapse. ${ }^{44}$ When a growth cone enters the area that it has been guided towards, new molecules (such as slit proteins) may not only exert their own effects but also switch off the effects of previously guiding molecules. ${ }^{47}$

Apoptosis or (genetically) programmed cell death plays an important role in the development of RGCs and their axons. ${ }^{48-51}$ Recently, interest has been focussed on the process of perverted apoptosis that may occur in diseases such as glaucoma (Table 1). ${ }^{52}$

\section{Developing RGC axons in the chiasm}

Normal vision is dependent on ordered neuronal maps of visual space which depend on precise connections between retinal axons and their target cells. In mammals, nerve fibres from the right and left eyes produce maps of contralateral visual space in adjacent layers of the lateral geniculate nucleus (LGN $)^{58}$ and in the superior colliculus and the pretectal nuclei and elsewhere.

Optic axons make binary decisions as to whether they decussate and project to the contralateral LGN or whether they remain ipsilateral. In primates, the ganglion cells that originate these axons lie perfectly spatially separated ${ }^{59}$ to the nasal (for fibres that cross) or temporal (uncrossed fibres) side of a line that runs vertically through the foveola. The control of crossing is complex (Figure 6); a number of guidance cues interact to conduct the crossover and have been the subjects of excellent reviews. ${ }^{60-62}$ EXT1 interacts with Slit proteins which are heparan sulphate-binding repulsive guidance 
Table 1 A chronology of ON development

\begin{tabular}{|c|c|c|}
\hline Gestational age & Event & Ref \\
\hline $4 / 40$ & First ganglion cell precursors appear near the foetal fissure & \\
\hline $6-7 / 40$ & Foetal fissure closes & \\
\hline $7 / 40$ & $\begin{array}{l}\text { Sensory retina divides into outer and inner neuroblastic layers, divided by a layer of } \\
\text { Chievitz }\end{array}$ & \\
\hline $7 / 40$ & $\begin{array}{l}\text { Cells in the inner neuroblastic layer migrate inwards, ganglion cells first, Müller cells next. } \\
\text { Ganglion cells first originate around the future optic disc, later more peripherally }\end{array}$ & 53 \\
\hline $8 / 40$ & Inner neuroblastic layer further differentiates & \\
\hline $8 / 40$ & $\begin{array}{l}\text { Ganglion cell axons exit the inner neuroblastic layer and extend towards the optic stalk and } \\
\text { form the retinal nerve fibre layer (NFL) and ON }\end{array}$ & \\
\hline $8-18 / 40$ & $\begin{array}{l}\text { RGC axons increase to } 1.9 \text { million at } 10 / 40 \text {, then increase to } 3.6 \text { million at } 14 / 40 \text {. Axon } \\
\text { diameter increases }\end{array}$ & 51 \\
\hline $8-18 / 40$ & Microglia actively phagocytosing degenerating RGC axons. & 54 \\
\hline $14-30 / 40$ & Apoptosis, greatest at 16-21 weeks, reduces RGC axons to $1.1-1.2$ million. By $29-30 / 40$ & $48,49,55$ \\
\hline Third month & $\begin{array}{l}\text { Differentiation of the retina is more advanced in the inner layers (RGCs) and least in the } \\
\text { outer layer (photoreceptors). Differentiation starts at the posterior pole and progresses to } \\
\text { the periphery }\end{array}$ & \\
\hline Fourth month & $\begin{array}{l}\text { Photoreceptor differentiation commences. ON meningeal development develops rapidly. } \\
\text { Dura, Pia, Arachnoid all have increased collagen and subarachnoid space differentiated }\end{array}$ & \\
\hline Fifth month & $\begin{array}{l}\text { Major photoreceptor differentiation. RGC axon apoptosis at its height phagocytosis is by } \\
\text { nearby RGCs, later by macrophages. Loss of axons is compensated for by increase in glial } \\
\text { cell structures and collagen }\end{array}$ & 51,56 \\
\hline Sixth month & $\begin{array}{l}\text { Maturation of RGCs starts from the posterior pole, moving peripherally, possibly related to } \\
\text { the now rapidly developing retinal vessels }\end{array}$ & 57 \\
\hline Seventh month & $\begin{array}{l}\text { Area centralis starts to differentiate into the macula by shifting of the RGCs away from the } \\
\text { future fovea. This is not by the process of apoptosis. Myelinization appears at the chiasm } \\
\text { and proceeds anteriorly }\end{array}$ & $48,53,53$ \\
\hline Eighth month & 1.1-1.3 Million RGC axons in the ON. Myelination nearly at the optic disc & 50 \\
\hline
\end{tabular}

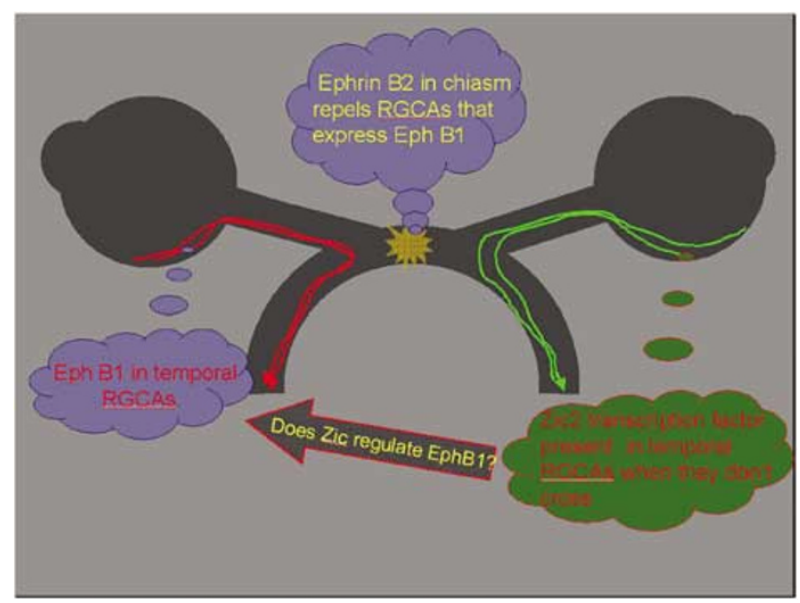

Figure 6 Ephrin-B2 in the mouse chiasm repels the axons which are to form the ipsilateral projection by selective inhibition. ${ }^{68}$ The transcription factor Zic2 is expressed in RGCs which are going to be uncrossed when they grow from the ventrotemporal retina towards the chiasm. ${ }^{66}$

cues $^{63}$ that establish a corridor through which axons are channelled. ${ }^{64}$ Slits are molecules secreted by midline glia that are inhibitory to 'Robo' receptors on RGC axons. However, they do not directly control RGC axon divergence at the optic chiasm and may additionally function as a general inhibitory guidance system involved in determining the relative position of the optic chiasm at the ventral midline. ${ }^{65} \mathrm{Zic} 2$ transcription factor, ${ }^{66} \mathrm{CD} 44,{ }^{67} \mathrm{Eph} \mathrm{B1},{ }^{68}$ which is the receptor for Ephrin B2, ${ }^{68}$ are also involved. It is likely that the very complex way in which these molecules interact, turn on, and turn off will emerge over the next years.

In most mammals there is incomplete separation of the crossed and uncrossed axon RGCs that cross in the chiasm, the crossed fibres come from all over the retina and the uncrossed fibres come from temporal to the Area Centralis, the nonprimate equivalent of the Macula. Binocular animals such as the cat ${ }^{69}$ have a larger proportion of uncrossed fibres.

In humans, the chiasm appears within the first month of life. ${ }^{70}$ The precursor of the chiasm appears as a thickening of the floor of the forebrain lying between the optic stalks at the junction of the telencephalon and the diencephalon. RGCs grow down the optic stalks and enter the floor of the third ventricle where they decussate to form the optic chiasm.

The highly specific pattern of axon crossing is fundamental to visual processing; its formation occurs in two phases. ${ }^{71,72}$ As the first retinal axons meet in the midline at the ventral diencephalons, they form an Xshaped chiasm; subsequent axons grow into either the 
ipsilateral or contralateral optic tract. As in the retina, foetal fissure, and $\mathrm{ON}$, each axon is tipped by a growth cone which allows the axon to sense and respond to signals in the embryonic brain environment. ${ }^{73,74}$ Routing errors are remarkably infrequent - in the order of only about 3-8/1000 RGCs! ${ }^{74}$

The chiasm reaches its definitive form by the fourth month of gestation.

\section{Apoptosis in the anterior visual system}

At first there is a substantial overproduction of neurons which later die back, as a result of apoptosis. ${ }^{49,50}$ The lumen of the optic stalk is initially open and in communication with the forebrain cavity. It closes by the end of the second month of gestation, when it elongates and the foetal fissure is formed. Closure of the foetal fissure in the optic stalk begins distally and proceeds towards the brain. After closure, the nerve fibres fill the whole nerve.

Abnormalities of a number of genes ${ }^{75,76}$ and axon guidance proteins $\mathrm{s}^{77}$ may result in abnormalities of chiasmal development.

\section{$R G C$ axons in the optic tracts}

GAP-43 is an intracellular growth cone protein which regulates calmodulin availability. It may mediate RGC axon interaction with guidance cues in the optic tract. ${ }^{78}$ Netrin- 1 and DCC, as well as their role in the retina and $\mathrm{ON}$, also govern both axon pathway formation and neuronal positioning during hypothalamic development, and affect both visual and neuro-endocrine systems. ${ }^{38}$ Slit proteins are also important.

\section{Gene regulation of midline structures}

The homeodomain transcription factor, HESX1, encodes a developmental repressor and is expressed in early development in a region which forms the forebrain, Rathke's pouch, and the primordium of the anterior pituitary gland. Mutations within the gene have been associated with septo-optic dysplasia ${ }^{79}$ and a constellation of other phenotypes. HESX1 does not act in isolation: other molecular mechanisms appear to influence or be influenced by HESX1 function. ${ }^{80,81}$

Other transcription factors that are known to affect development in the region of the pituitary gland include LHX3, LHX4, PROP1, PITX1, PITX2, SIX6, TPIT, and PIT1. PAX2 may interrelate with PAX6 to produce a variety of effects ${ }^{82}$

\section{Consequences to the visual system of abnormal development}

\section{Optic nerve aplasia (ONA)}

There have been a number of reports of absence of the optic discs associated with widespread developmental abnormalities of the anterior visual system, anophthalmos in particular: these are histological, anatomical, or, more recently, neuroimaging studies. Mostly, these cases have come to diagnosis because of their ophthalmoscopic appearance: hence, the term often used is Optic Disc Aplasia. Newman ${ }^{83}$ was the first to clearly describe ONA in humans, just a few years after the introduction of the ophthalmoscope: two blind sisters in a nonconsanguineous family of eight children had normal-sized eyes but no perception of light; one had roving eye movements which made ophthalmoscopy difficult. 'No appearance of optic disc, retinal vessels or yellow spot, but an irregularly star-shaped patch of dark nonvascular appearance occupies the place of the disc'. He went on to describe the pupil reactions which have cast doubt on whether this was truly a description of $\mathrm{ONA}^{84}$ but the ophthalmoscopic description is so clear as to be difficult to doubt.

ONA is diagnosed in a blind eye where there is no optic disc and no retinal vessels, but the occurrence of partial cases, cases with a few retinal blood vessels, or an area in the fundus that corresponds to an optic disc, make it unnecessary to be too pedantic about what is and what is not ONA.

\section{Diagnostic criteria}

The optic disc is absent or rudimentary.

There are no, or few and abnormal retinal vessels.

The vision is extremely poor or absent.

There is sometimes a coloboma of the fundus or iris.

There may be a retinal pigment disturbance especially at the site where the optic disc might have been.

There may be other eye and systemic developmental defects.

Retinal dysplasia is frequent in histopathological cases. Choroidal neovascularization is an occasional finding.

\section{Theories of aetiology and pathogenesis}

(1) There is a primary failure of ganglion cells to develop. ${ }^{14,85}$

- Other retinal elements are present in the retina and, since the ganglion cells are the first to develop from progenitor cells, if RGCs were missing, the other elements would also be absent.

- The presence of dysplastic retina ${ }^{85,86}$ may suggest an early, widespread process affecting some or all classes of cells arising from the progenitor cells.

- Other CNS malformations are frequent and may be due to abnormalities of other CNS neuron development.

(2) There is a failure of RGC axon initiation and/or guidance, so the axons do not 'sprout' or they fail to reach the optic disc. 
Table 2 ONA literature review

\begin{tabular}{|c|c|c|c|c|}
\hline Authors and citation & Clinical & Neurophysiology & Neuroimaging & Histopathology \\
\hline Newman $(1864)^{83}$ & $\begin{array}{l}\text { Two sisters without other family history. No optic disc or } \\
\text { vessels, Dark patch in place of disc. Nl sized eyes. Pupil } \\
\text { reactions described }\end{array}$ & Not done & Not done & Not done \\
\hline Brière $(1877)^{91}$ & 7 yo blind girl. No discs. CRA + CRV present. Choroid Nl & Not done & Not done & Not done \\
\hline Magnus $(1884)^{92}$ & $\begin{array}{l}\text { R. unilateral. No disc. White sickle-shaped area with } \\
\text { pigmented border. Retinal vessels from temporal periphery }\end{array}$ & Not done & Not done & \\
\hline Von Meisner $(1911)^{93}$ & R. unilateral, no disc, no vessels, no fovea & Not done & Not done & Not done \\
\hline Young $(1940)^{94}$ & $\begin{array}{l}\text { Blind LE from birth. No disc or retinal vessels Fundus } \\
\text { pigmented like a tapetum }\end{array}$ & Not done & Not done & Not done \\
\hline Warfel $(1961)^{89}$ & $\begin{array}{l}80 \text { yo dissection cadaver found to have rudimentary R eye } \\
\text { and no R ON }\end{array}$ & Not done & Not done & $\begin{array}{l}\text { Rudimentary eye with lens. Orbit } \\
\text { basically normal }\end{array}$ \\
\hline $\begin{array}{l}\text { Hotchkiss and Green }(1970)^{86} \\
\text { Case } 1\end{array}$ & $\begin{array}{l}8 / 12 \text { female with } \mathrm{R} \text { microphthalmos and choroidal } \\
\text { coloboma. No ON after enucleation. Unilateral }\end{array}$ & Not done & Not done & $\begin{array}{l}\text { Funnel RD + PHPV. RGCs + NFL absent. } \\
\text { Coloboma }\end{array}$ \\
\hline $\begin{array}{l}\text { Hotchkiss and Green }(1970)^{86} \\
\text { Case } 2\end{array}$ & $\begin{array}{l}\text { ? Hallermann-Strieff. Dev delay. Died of heart disease. Optic } \\
\text { tracts and chiasm present. Only R ON. No L. ON and large } \\
\text { coloboma }\end{array}$ & Not done & Not done & $\begin{array}{l}\text { RGCs \& NFL absent. No RBVs. Retinal } \\
\text { dysplasia. Postero-temporal coloboma }\end{array}$ \\
\hline $\begin{array}{l}\text { Hotchkiss and Green }(1970)^{86} \\
\text { Case } 3\end{array}$ & Multiple congenital anomalies inc. radial aplasia. No ON & Not done & Not done & $\begin{array}{l}\text { Three small colobomas. No RGCs, RBVs, } \\
\text { or OD }\end{array}$ \\
\hline Renelt $(1972)^{95}$ & $\begin{array}{l}4 / 12 \text { old with R anophthalmos and L microphthalmos with } \\
\text { no OD or RVs }\end{array}$ & Not useful & & Not done \\
\hline Hoff et al $(1975)^{96}$ & $\begin{array}{l}49 \text { yo. R anophthalmos LHHH + total HH. At Sx, ON small } \\
\text { inserted directly into tract. No chiasm. R optic foramen } \\
\text { contained only ophthalmic artery }\end{array}$ & Not done & $\begin{array}{l}\text { ICA }+ \text { AEG } \\
\text { showed } \\
\text { suprasellar } \\
\text { aneurysm }\end{array}$ & Not done \\
\hline Little et al (1976) ${ }^{84}$ & $\begin{array}{l}\text { Unilateral. L microphthalmos. No retinal vessels, grey pit } \\
\text { surrounded by pigmented ring. Two colobomatous defects. R } \\
\text { Normal }\end{array}$ & $\begin{array}{l}\text { ERG present. B } \\
\text { wave attenuated }\end{array}$ & Not done & Not done \\
\hline Weiter et al (1977) ${ }^{85}$ & $\begin{array}{l}\text { 13 pathological cases. ? foetal fissure defect. Coloboma in 11/ } \\
\text { 13. Retinal dysplasia in 10/13. } 2 \text { bilateral-? RGC failure }\end{array}$ & Not done & Not done & $\begin{array}{l}\text { 10/13 Absent disc and vessels. Vestigial } \\
\text { dural sheath: pigment where dural } \\
\text { sheath attached to globe }\end{array}$ \\
\hline Yanoff $(1978)^{97}$ & Widespread brain malformations. Bilateral & Not done & Not done & $\begin{array}{l}\mathrm{Nl} \text { sized eyes. RGCs reduced with few } \\
\text { axons or dendrites. Rudimentary papilla } \\
\text { with no axons }\end{array}$ \\
\hline Ginsberg et al (1980) $)^{98}$ & $\begin{array}{l}\text { Unilateral. Aniridia. No retinal vessels or disc. Cardiac } \\
\text { anomalies, died at } 4 / 7\end{array}$ & Not done & Not done & Retinal dysplasia \\
\hline Storm and Pibenito $(1984)^{99}$ & $\begin{array}{l}\text { Bilateral ODA. Hydranencephaly. Consanguinity ?AR. 1ry } \\
\text { RGC failure? }\end{array}$ & Not done & Not done & Not done \\
\hline Barry $(1985)^{100}$ & $\begin{array}{l}\text { Transposition of great vessels. Died at } 5 / 7 \text {. Brain basically } \\
\text { normal }\end{array}$ & Not done & Not done & $\begin{array}{l}\text { R cornea opaque. No discs, retinal blood } \\
\text { vessels, RGCs, ONs or chiasm. Retinal } \\
\text { dysplasia. Coloboma in one eye }\end{array}$ \\
\hline Margo et al (1992) $)^{101}$ & R microphthalmia. L MLN. VA20/50 & $\begin{array}{l}\text { VEP. Authors } \\
\text { suggest }\end{array}$ & Absent R ON & $\begin{array}{l}\text { Disorganized and gliotic retina. } \\
\text { RPE + choroid mostly absent, some } \\
\text { areas hyperplastic }\end{array}$ \\
\hline
\end{tabular}


Table 2 (Continued)

\begin{tabular}{|c|c|c|c|c|}
\hline Authors and citation & Clinical & Neurophysiology & Neuroimaging & Histopathology \\
\hline & & $\begin{array}{l}\text { excessive } \\
\text { crossover }\end{array}$ & & \\
\hline Blanco et al $(1992)^{102}$ Case 1 & $\begin{array}{l}\text { Normal 5/12 female with } \mathrm{R} \text { microphthalmos. Fundus RPE } \\
\text { atrophy, and ?retinal vessel coming from disc area. L normal }\end{array}$ & $\begin{array}{l}\text { ERG attenuated. } \\
\text { VEP 'normal' }\end{array}$ & Not done & Not done \\
\hline Blanco et al $(1992)^{102}$ Case 2 & $\begin{array}{l}\text { Delayed 5/12 blind female. No retinal vessels, grey-white } \\
\text { discs }\end{array}$ & $\begin{array}{l}\text { ERG \& VEPs. } \\
\text { 'normal' }\end{array}$ & $\begin{array}{l}\text { CT cerebral } \\
\text { atrophy, thin } \\
\text { ONs }\end{array}$ & Not done \\
\hline Blanco et al $(1992)^{102}$ Case 3 & $\begin{array}{l}1 / 12 \text { male. } \mathrm{R} \text { clinical anophthalmos, } \mathrm{L} \mathrm{Nl} \text { sized eye with no } \\
\text { retinal vessels and a cavity where the optic disc should be. At } \\
5 / 12 \text { new vessels at disc, retinal detachment }\end{array}$ & ERG Normal & & Not done \\
\hline Peiffer et al (1992) ${ }^{103}$ & Bilateral, microphthalmos. Agnathia. Retinal dysplasia & Not done & Not done & Not done \\
\hline Howard et al $(1993)^{101,104}$ & $\begin{array}{l}\text { No R optic disc. No retinal vessels. Areas of increased and } \\
\text { decreased pigment. B-scan showed no ON }\end{array}$ & $\begin{array}{l}\text { R ERG flat. L } \\
\text { normal }\end{array}$ & $\begin{array}{l}\text { MRI absent R } \\
\text { ON. Brain } \\
\text { normal }\end{array}$ & Not done \\
\hline Lee et al $(1996)^{105}$ Case 1 & $\begin{array}{l}\text { Bilateral coloboma, microphthalmos, persistent pupillary } \\
\text { membranes RPE Mottling }++ \text { No disc or retinal vessels. } \\
\text { Neovascularisation }\end{array}$ & $\begin{array}{l}\text { No ERG } \\
\text { response }\end{array}$ & $\begin{array}{l}\text { 'Septo-optic } \\
\text { dysplasia' on } \\
\text { MRI }\end{array}$ & Not done \\
\hline Lee et al $(1996)^{105}$ Case 2 & $\begin{array}{l}\text { R. microphthalmos. Persistent pupillary membranes. Retinal } \\
\text { and pre-retinal Hgges. Neovascular fronds. L retinal vessels } \\
\text { anomalous }\end{array}$ & Not done & $\begin{array}{l}\text { CT Nl brain. No } \\
\text { R ON }\end{array}$ & Not done \\
\hline Scott et al (1997) ${ }^{106}$ & $\begin{array}{l}\text { No light perception. Bilateral colobomas (Iris), } \\
\text { microphthalmos, R dysplastic retina, } \mathrm{R}+\mathrm{L} \text { 'ONA'. Healthy } \\
\text { child }\end{array}$ & Not done & $\begin{array}{l}\text { Absent ONs, } \\
\text { chiasm and } \\
\text { tracts. Pituitary } \\
\text { stalk normal }\end{array}$ & Not done \\
\hline Pieramici et al $(2001)^{107}$ & $\begin{array}{l}\text { At } 23 \text { yo } R \text { microphthalmos ODA. NLP. RPE hypertrophy/ } \\
\text { atrophy at } 29 \text { yo found to have asymptomatic Choroidal } \\
\text { neovascularization }\end{array}$ & Not done & $\begin{array}{l}\text { MRI-absent R } \\
\text { ON }\end{array}$ & Not done \\
\hline Brodsky et al (2004) $)^{108}$ & $\begin{array}{l}\mathrm{R}+\mathrm{L} \text { microphthalmos. ODA. FH. } \mathrm{M}=\text { hypothyroid. Multiple } \\
\text { endocrine abnormalities }\end{array}$ & Not done & $\begin{array}{l}\text { Posterior } \\
\text { pituitary } \\
\text { ectopia. Absent } \\
\text { ONs }\end{array}$ & Not done \\
\hline
\end{tabular}

Yo=year old; $\mathrm{AR}=$ autosomal recessive; $\mathrm{CRA} / \mathrm{V}=$ central retinal artery/vein; $\mathrm{CT}=$ computed tomography; $\mathrm{ERG}=$ electroretinogram; $\mathrm{HH}=$ homonymous hemianopia; HHH $=$ homonymous hemioptic hypoplasia; $\mathrm{MLN}=$ manifest latent nystagmus; $\mathrm{MRI}=$ magnetic resonance imaging; $\mathrm{NFL}=$ nerve fibre layer; $\mathrm{Nl}=$ normal; $\mathrm{NP}=$ normal pregnancy; $\mathrm{NLP}=$ no light perception; $\mathrm{ODA}=\mathrm{optic}$ disc aplasia; $\mathrm{PHPV}=$ persistent hyperplastic primary vitreous; $\mathrm{RBV}=$ retinal blood vessel; $\mathrm{RD}=$ retinal detachment; $\mathrm{RGC}=$ retinal ganglion cell; $\mathrm{RPE}=$ retinal pigment epithelium; $\mathrm{VEP}=$ visually evoked potential. 
(3) There is a failure of the mesodermal elements to grow normally. ${ }^{14}$ However, the ON sheath is present in many pathological cases. ${ }^{85}$

(4) There is an abnormality of foetal fissure formation or closure. ${ }^{87}$

- RGCs crossing colobomas die off. ${ }^{88}$

- Coloboma is an association.

(5) There is an initial development of the eye with subsequent 'degeneration'. ${ }^{89}$

(6) It is a failure of genetic control of development. The fact that $\mathrm{ONH}$ and not ONA results when there is lack of Netrin-1 function in mice suggests that there are a number of mechanisms that act on subsets of axons during growth. ${ }^{90}$ Familial cases do occur.

Systemic associations

The literature is not clear as to the prevalence of systemic abnormalities in children with ONA. While unilateral cases are usually otherwise normal, bilateral cases may have associated brain, cardiac, and other abnormalities (Tables 2 and 3).

From our cases and from the literature, it appears that there may be three groups of cases:-

(1) Cases with a grossly normal choroid but absent retinal vessels and no ophthalmoscopically visible optic disc. The ERG may be present, but abnormal (Figure 7).
(2) Cases with a severely abnormal hyper/hypopigmented fundus, abnormal choroid, absent retinal blood vessels and absent optic disc. The ERG is absent (Figure 8).

(3) Cases that have signs of fetal fissure closure defects (colobomas) but with no visible disc or an extremely

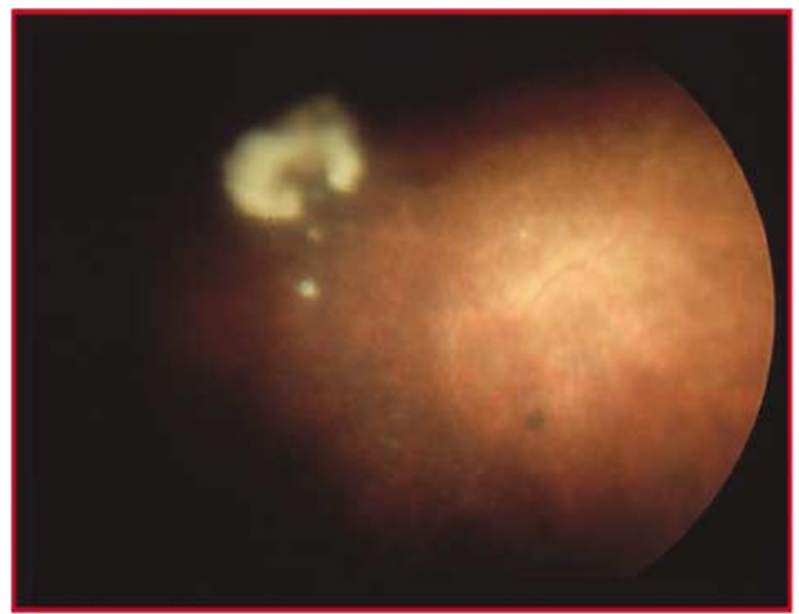

Figure 7 Type 1 ONA. There was no optic disc or retinal vessels visible at examination under anaesthetic. There was a white solid object in the posterior vitreous. The illustration was provided by the courtesy of Miss Isabelle Russell-Eggitt.

Table 3 ONA patients at Great Ormond Street

\begin{tabular}{|c|c|c|c|c|c|}
\hline $\begin{array}{l}\text { Patient sex and } \\
\text { ID }\end{array}$ & Presentation & Pregnancy and family history & Clinical & $E R G$ and $V E P$ & Neuroimaging \\
\hline $\begin{array}{l}\text { Case } 1 \text { F } 707510 \\
\text { (Figure 7) }\end{array}$ & $\begin{array}{l}\text { Eyes small from } \\
\text { birth }\end{array}$ & $\begin{array}{l}38 / 40 \text { NP. One healthy sib, } \\
\text { one stillbirth at } 38 / 40 \text {. No } \\
\text { consanguinity }\end{array}$ & $\begin{array}{l}\text { HCDs R } 6.5 \text { mm L } 7.75 . \\
\text { Persistent pupillary } \\
\text { membranes. Lenses clear. } \\
\text { Granular RPE. No disc or } \\
\text { vessels. White elevated } \\
\text { area with grey 'cord' } \\
\text { extending anteriorly at } \\
\text { posterior pole. At } 3 \text { year 9/ } \\
12 \text { Reynell-Zinkin } \\
\text { scales-around age- } \\
\text { equivalent on all subscales. } \\
\text { Otoacoustic emissions } \\
\text { present }\end{array}$ & $\begin{array}{l}\text { Small, degraded } \\
\text { ERG. No flash } \\
\text { VEPs detected }\end{array}$ & $\begin{array}{l}\text { MRI at thready } \\
\text { nerves, and } \\
\text { chiasm. Nl } \\
\text { myelination. } \\
\text { Corpus callosum } \\
\text { intact }\end{array}$ \\
\hline $\begin{array}{l}\text { Case } 2 \text { WF M } \\
704426 \text { (Figure 8) }\end{array}$ & $\mathrm{R}$ eye small & Nil relevant & $\begin{array}{l}\text { Hypospadias. } \mathrm{R} \\
\text { microphthalmos, }-7.0 \\
\text { myopia R eye; Nl choroid, } \\
\text { no macula. No disc visible } \\
\text { but a few RBVs emerge } \\
\text { from linear area. L eye } \\
\text { normal }\end{array}$ & $\begin{array}{l}\text { L. ERG + PVEP. } \\
\text { N1. R.ERG small. } \\
\text { FVEP absent }\end{array}$ & Not done \\
\hline $\begin{array}{l}\text { Case } 3 \text { PW F } \\
\text { (Figure 9) }\end{array}$ & $\begin{array}{l}\text { Dysmorphism. } \\
\text { blindness }\end{array}$ & Nil relevant & $\begin{array}{l}\text { Microcephaly, sloping } \\
\text { forehead, developmental } \\
\text { delay }\end{array}$ & $\begin{array}{l}\text { No VEP or ERG } \\
\text { detectable }\end{array}$ & Normal CT \\
\hline
\end{tabular}

$\overline{\mathrm{CT}}=$ computed tomography; $\mathrm{ERG}=$ electroretinogram; $\mathrm{MRI}=$ magnetic resonance imaging; $\mathrm{Nl}=$ normal; $\mathrm{RBV}=$ retinal blood vessel; $\mathrm{RPE}=$ retinal pigment epithelium; VEP = visually evoked potential. 


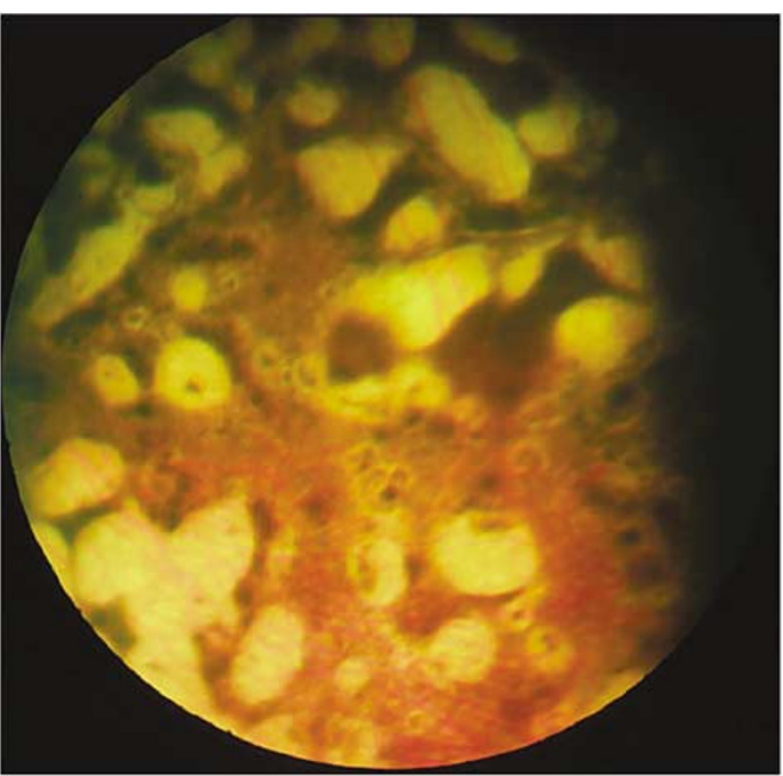

Figure 8 Type 2 ONA in a 1-year-old girl with microcephaly. There was no optic disc or retinal vessels demonstrated on examination under anaesthetic, including a fluorescein angiogram. The other eye had an area which could have been an optic disc, but there were no retinal vessels. The choroid and retinal pigment epithelium are dysplastic.

abnormal disc. Retinal vessels may be present but are of abnormal origin and distribution. The ERG is present (Figure 9, Table 4).

\section{Optic nerve hypoplasia}

\section{Definition}

$\mathrm{ONH}$ is an abnormality of the optic disc that occurs before the full development of the optic associated with a reduced population of RGC axons.

\section{Presentation}

Bilateral, severe, $\mathrm{ONH}$ presents as blindness in early infancy with roving eye movements and sluggish or absent pupil reactions to light. Lesser degrees of bilateral hypoplasia may cause minor visual defects or squint at any time in childhood and may even be found without symptoms at a routine test. Unilateral ONH usually
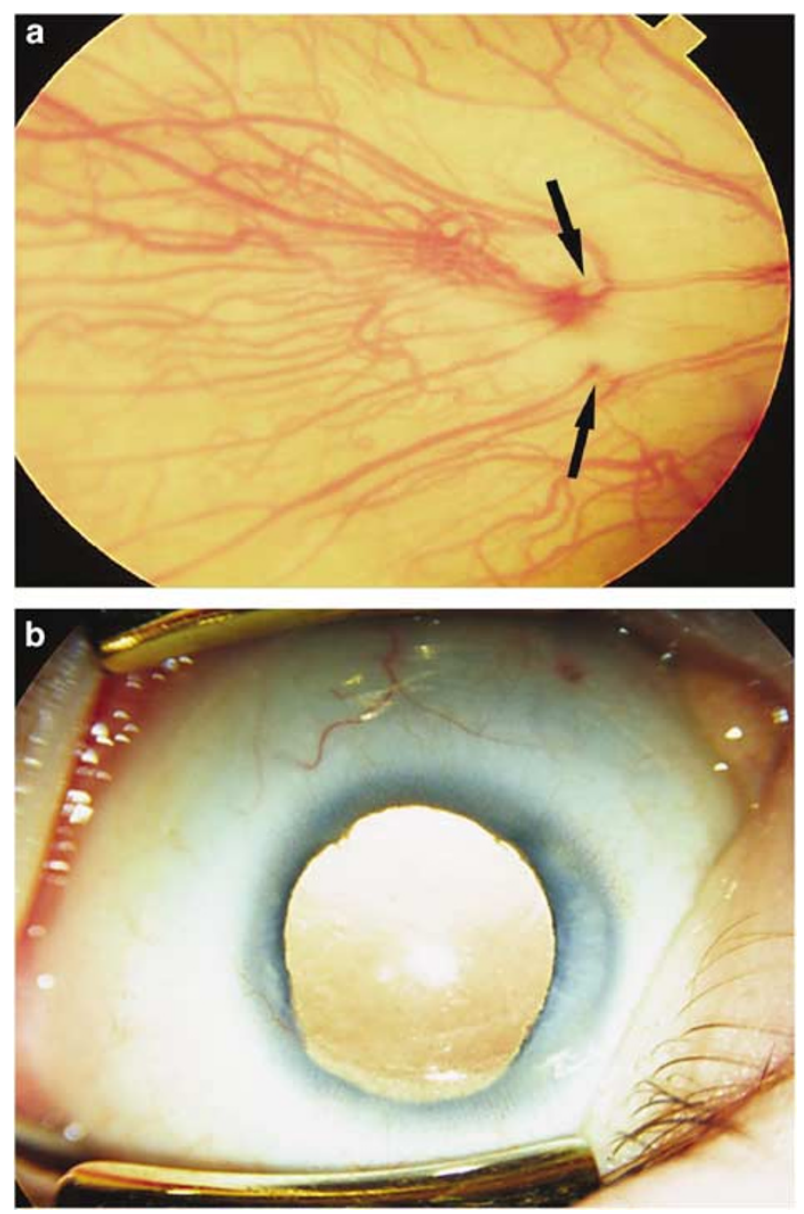

Figure 9 (a) Type 3 ONA. There are a few retinal vessels which appear to come out of two areas in the choroid. No optic disc was visible at examination under anaesthetic. The ERG was relatively well preserved but the VEP was absent. (b) Same case. There was a coloboma of the iris on the affected side. The other eye was normal.

presents as strabismus with a relative afferent pupil defect and unsteady fixation in the affected eye. The eye movement defect may resemble 'see-saw' nystagmus. ${ }^{109}$ Amblyopia may contribute to the poor visual acuity and especially if the discs are not markedly hypoplastic the vision may improve with patching. ${ }^{110}$ Astigmatism may be a frequent association. ${ }^{111}$ There has been some debate as to whether, in hypermetropic eyes with amblyopia, there is an element of $\mathrm{ONH} .{ }^{112-114}$

Table 4 A classification of ONA

\begin{tabular}{lllllll}
\hline & Optic disc & Retinal vessels & Choroid & ERG & VEP & Coloboma \\
\hline Group 1 (Figure 7) & Not visible & Absent & Grossly normal & Present, abnormal & Absent & No \\
Group 2 (Figure 8) & Not visible & Absent & Severely abnormal & Absent & Absent & No \\
Group 3 (Figure 9) & Not really visible & Some present & Grossly normal & Present _normal & Severely abnormal & Present \\
\hline
\end{tabular}


Affected patients may present because of failure to thrive in infancy or as a result of a variety of endocrine disorders (see below). Hypoplastic discs occur more frequently in males than females, and probably without racial predilection. ${ }^{115}$ The parents of children with optic disc hypoplasia tend to be young primiparae. ${ }^{116,117}$ Less frequently, children present because of the abnormalities from the associated brain defects.

The appearance of the hypoplastic optic disc in children Severe ONH: The true disc substance is minute (Figure 10) and often only identifiable as a slightly pink-yellow area from which the retinal vessels emerge. This area is surrounded by an area of exposed sclera which is roughly circular and appears to represent the area of the gap in the retinal pigment epithelium that is present when the disc is of normal-size. The overall area of the optic disc (outer ring) is composed of bare sclera or cribriform plate; this is variably larger than the circular area (inner ring) of the retinal nerve fibres (the minute optic disc itself) and the appearance of the two concentric circles is known as the 'double ring' sign (Figure 10).

There are reduced retinal nerve fibres and normal-sized retinal vessels. In severe $\mathrm{ONH}$, the double ring is often very marked.

Sometimes there is proliferation of the retinal pigment epithelium on this normally white ring (Figure 11), but more usually there is a small rim of pigment around part of the margin of the white area. The retinal vessels, veins particularly, are often rather more tortuous than normal, ${ }^{118-120}$ but this has not been evident in all studies. The retinal NFL is variably thinned, ${ }^{121,122}$ and if the hypoplasia is segmental this thinning is also segmental. It is the white ring of sclera that is so often confused for a

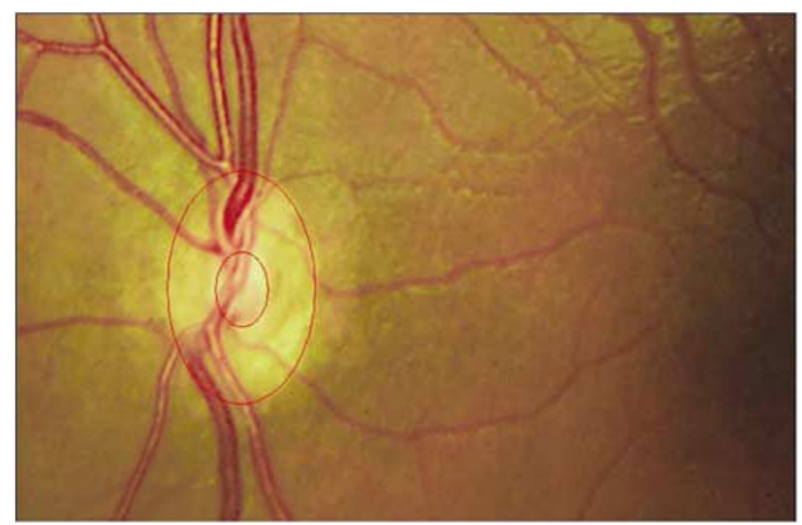

Figure 10 The overall area of the optic disc (outer ring) is composed of bare sclera or cribriform plate; this is variably larger than the circular area (inner ring) of the retinal nerve fibres (the minute optic disc itself) and the appearance of the two concentric circles is known as the 'double ring' sign. There are reduced retinal nerve fibres and normal-sized retinal vessels. In severe $\mathrm{ONH}$, the double ring is often very marked. normal sized, but atrophic disc and this mistake is more easily made by those who use only indirect ophthalmoscopy.

Moderate and mild ONH: One of the difficulties in diagnosis arises when optic disc hypoplasia is anything less than extreme. Frisen and Holmegaard ${ }^{123}$ pointed out that there was a very wide variation in the appearance of hypoplastic optic discs and that their effect on vision is also widely variable; hypoplasia is a nonspecific manifestation of damage to the visual system that was sustained at any time before its full development. Notches occur in the disc and NFL defects are associated with a relative smallness and irregularity in the outline of the disc in the fellow eye.

The 'double ring sign' is often present; the outer ring of the double-ring sign, seen ophthalmoscopically (Figure 12), represents pathologically the junction between the sclera and the lamina cribrosa, and the inner ring corresponds to an abnormal extension of the retina and pigment epithelium over the outer portion of the lamina cribrosa. ${ }^{86,124}$ Changes may often be very subtle in the less affected optic disc, but may be useful additional clues, but the sign should be used in the context of changes in the disc as a whole; by itself it is not pathognomonic of $\mathrm{ONH}$ and, in mild degrees, occurs not uncommonly as an incidental finding in normal eyes (Figure 13).

Measurement of the optic disc size remains difficult, even if the optics of the eye are known and the ophthalmoscopic diagnosis is subjective, but some objectivity can be introduced by comparing ratios of vessel size and optic disc size or the disc-macula to disc

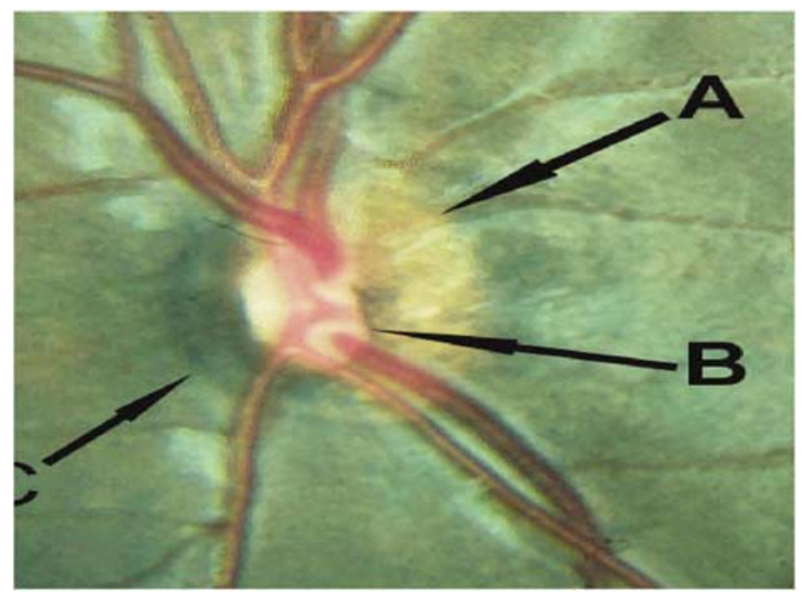

Figure 11 The outer ring of the double-ring sign seen ophthalmoscopically (Figure 12) represents pathologically the junction between the sclera and the lamina cribrosa (a), and the inner ring corresponds to the optic disc itself and as many nerve fibres as it may contain (b). There may be an abnormal extension of retinal pigment epithelium over the outer portion of the lamina cribrosa (c). 


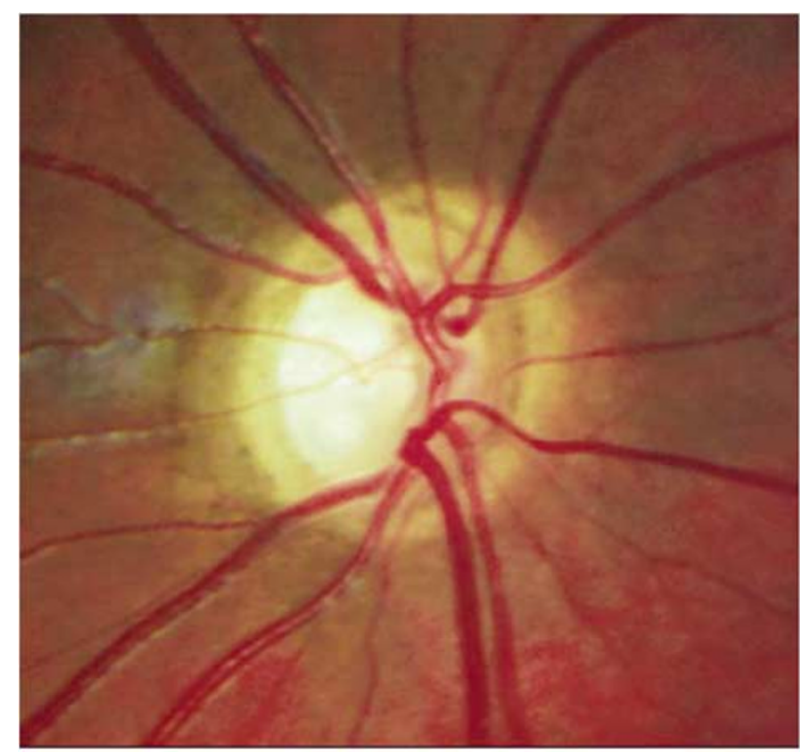

Figure 12 Mild to moderate ONH. This was a bilateral, symmetrical, case with good visual function: this is the right optic disc. The optic disc substance is slightly pale and is surrounded by a white ring with a little pigmentation. Outside this is another partial ring, mostly nasally, which may represent the end of the retinal pigment epithelium.

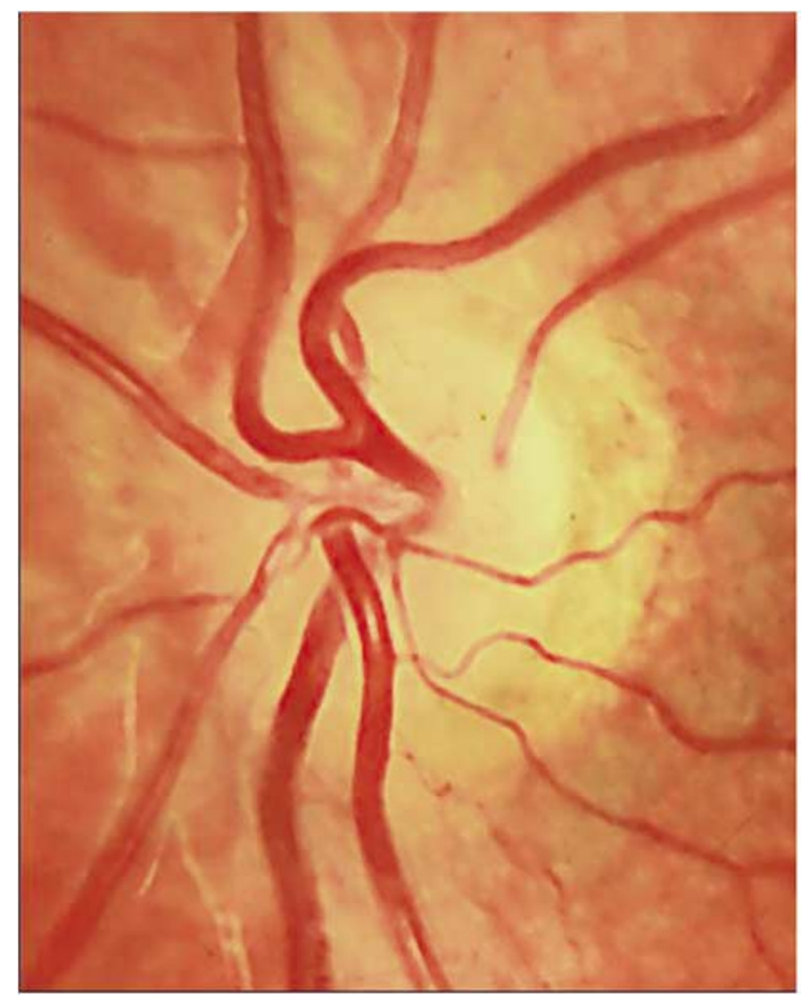

Figure 13 A double ring was found in both eyes in this asymptomatic, healthy child with $-0.1 \log$ MAR acuity and normal colour vision bilaterally. The patient was too young for visual field testing. There is a cilioretinal artery. A ring, by itself, is not pathognomonic of $\mathrm{ONH}$.

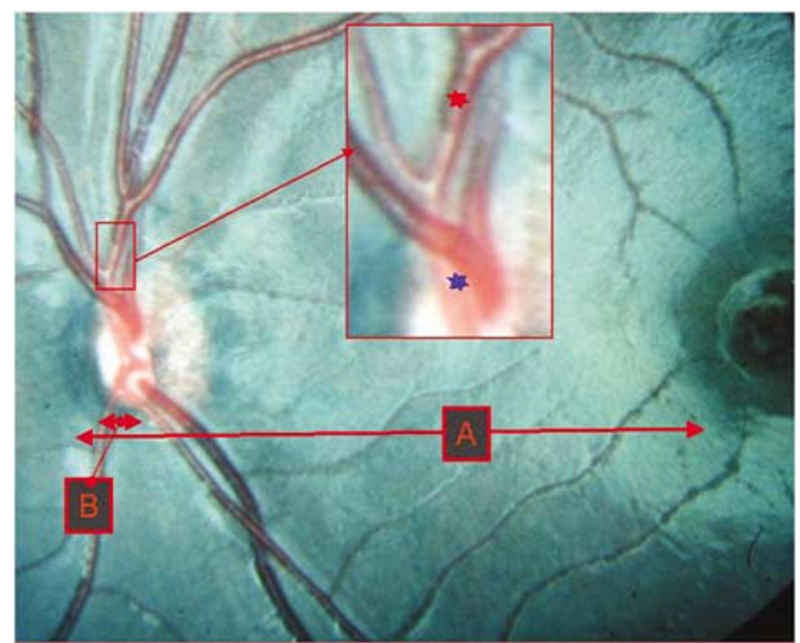

Figure 14 The size of the optic disc can be estimated by measuring the ratio of the disc diameter $(B)$ to either the diameter of a blood vessel or the distance between the disc edge and the macula $(A)$ that is $A / B$. If the ratio is over 3 , it may be more likely that the nerve is hypoplastic. There are limitations to any such technique; not least that visual function does not closely correlate with disc size. ${ }^{126}$

diameter ratio ${ }^{125,126}$ (Figure 14). MRI may be better than photographic analysis when compared with clinical examination. ${ }^{127}$ The techniques of ultrasound, photogrammetry, ${ }^{128,129}$ or optical coherence tomography ${ }^{130}$ may be helpful. However, the diagnosis of ONH cannot be made on size alone.

Isolated optic atrophy: In optic atrophy, the optic disc is of full size; there are no signs of any developmental abnormality such as a double ring sign, and the colour is variably pale due to the loss of nerve fibres.

$\mathrm{ONH}$ and atrophy: When the remaining optic disc is pale, perhaps implying further loss of axons after the basic (hypoplastic) disc outline has been laid down, this is known as hypoplasia with atrophy (Figure 15); it is quite frequently found. ONH merges imperceptibly with optic atrophy, depending on the severity and timing of the insult ${ }^{17}$ and in mild or severe $\mathrm{ONH}$, the remaining disc substance may be atrophic.

Vision and associated features: Severe hypoplasia causes blindness, but in lesser degrees a variety of abnormalities have been described, with some patients having clinically normal visual acuity ${ }^{131-133}$ although field defects in those cases with good acuity are common. ${ }^{133}$ Visual acuity is determined largely by the size of the papillomacular bundle, not with the overall size of the disc; there is not a very close correlation between the size of the optic disc and the visual function. ${ }^{126}$ The final vision may to an extent be predicted from assessment of the optic disc size ${ }^{134}$ the initial acuity card assessment and VEPs. ${ }^{129,135}$ Reassessment is important in infants as 


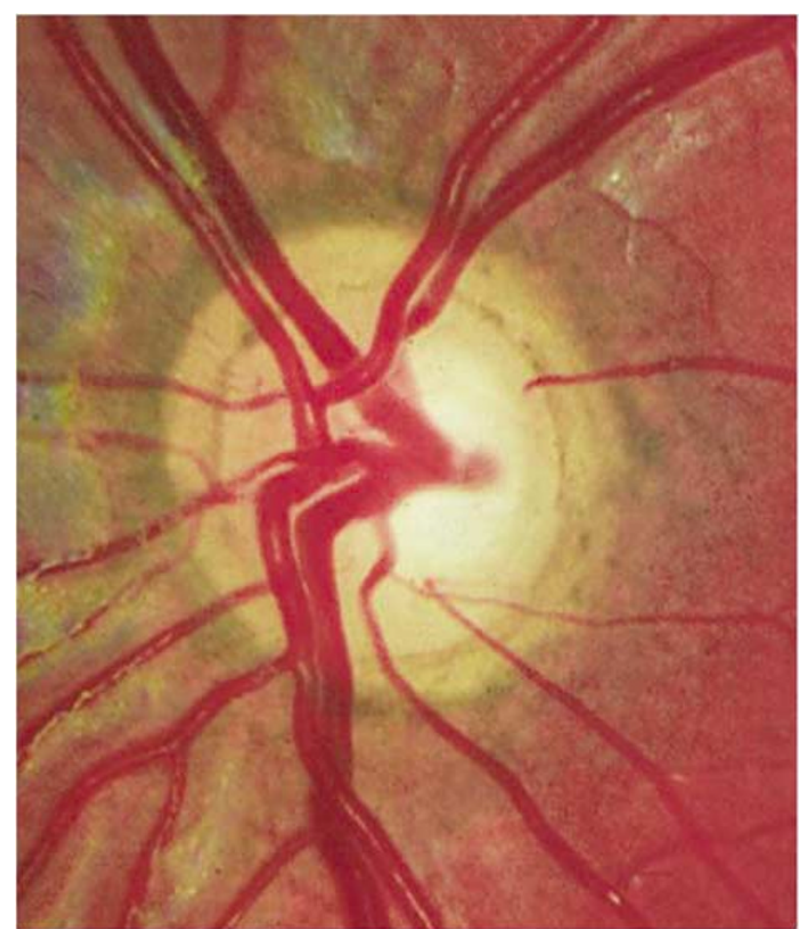

Figure $15 \mathrm{ONH}$ with atrophy. There is mild pallor of the optic disc substance in this mildly hypoplastic optic disc in a child who was born after 29 weeks gestation when his mother was severely injured in a car crash.

there may be an element of visual immaturity or delayed visual maturation. ${ }^{135}$

Refraction of every child with $\mathrm{ONH}$ is important as there may be an association with astigmatism. ${ }^{111}$ In patients with high myopia and optically incorrectable poor vision, it has been suggested that the cause may not only be amblyopia but also a physical defect, including ONH. ${ }^{136}$

The diagnostic hallmarks of visual field defects due to hypoplasia are that they are static and that there are ophthalmoscopic correlates of the field defects. ${ }^{123}$ Patients with a diffuse deficit of nerve fibres have more or less concentric visual field contraction and often a lowered acuity, but when the lack of nerve fibres is focal, the field defects are also focal.

Temporal visual field defects ${ }^{109,137,138}$ have been described, and this may indicate a chiasmal location of the primary anomaly. ${ }^{123}$

Retrochiasmal lesions associated with hypoplastic discs may also have appropriate homonymous field defects. If unilateral these are clear-cut, but if the defect is bilateral the homonymous character is usually lost. Central visual field defects ${ }^{138,139}$ and binasal defects ${ }^{12}$ have also been described.

The flash ERG is usually normal in optic disc hypoplasia. Colour vision is usually decreased, nonspecifically, roughly in proportion to the acuity defect.

Other features: Roving eye movements and unsteady fixation associated with poor vision, and see-saw nystagmus have been described, ${ }^{109}$ again suggesting a chiasmal abnormality. If there is early-onset nystagmus in a child with a moderate $\mathrm{ONH}$, the nystagmus may improve and even disappear with time. There may be abnormal optokinetic nystagmus. ${ }^{140}$ A variety of different types of strabismus have been described, usually in patients with poor vision. The optic canal is not necessarily small, ${ }^{119}$ but small ONs are found on CT scanning ${ }^{141}$ or magnetic resonance imaging (MRI). ${ }^{142}$

Segmental hypoplasia and the tilted disc: Dorrell ${ }^{143}$ pointed out that the familiar tilted disc, in which the optic disc is D-shaped, is accompanied by a defect in the retinal NFL adjacent to the flat arm of the ' $\mathrm{D}$ ', usually inferiorly. He found that nearly half of the patients he tested had nonrefractive visual abnormalities associated with the defect, and he pointed out the prenatal origin of the condition, suggesting that it represents a form of segmental hypoplasia. These true visual field defects ${ }^{143-}$ 146 are frequently superotemporal ${ }^{145,147}$ and this must be remembered in the evaluation of the visual fields when there is no neurological cause found for the defect. Tilted optic discs may also be mistaken for mild papilloedema. ${ }^{146}$ The concurrence in congenital X-linked stationary night-blindness, of myopia and tilted optic discs, ${ }^{148}$ is common.

The segmental nature is probably related to the site of the original lesion, ${ }^{149}$ a common but not invariable cause, when the hypoplasia affects the upper part of the optic disc is maternal diabetes (see below). Prenatal chiasmal damage produces hypoplasia of the nasal and temporal of the disc with a corresponding NFL deficit

(Figure 16). ${ }^{149}$

Situs inversus: Situs inversus is a more widespread defect in which the vessels emerging from the often small optic disc are so distorted that, together with the appearance resulting from the tilt per se, the disc appears to be rotated through approximately $180^{\circ}$ (Figure 17). Fuchs $^{150}$ (1882) considered this anomaly to be related to coloboma. In patients with these bilateral dysplastic optic discs, upper bitemporal relative visual field defects may occur, which cross the midline. There may be an associated posterior staphyloma below the disc (Figure 17). In many cases the apparent field defect disappears with appropriate optical correction of the myopia caused by the staphyloma.

ONH in children with periventricular leucomalacia $(P V L)$ : Jacobson et al ${ }^{151,152}$ suggested that children with PVL, the brain lesion seen in preterm infants who suffer perinatal hypoxic-ischaemic events that usually affect the corticospinal or geniculocalcarine tracts, might have 

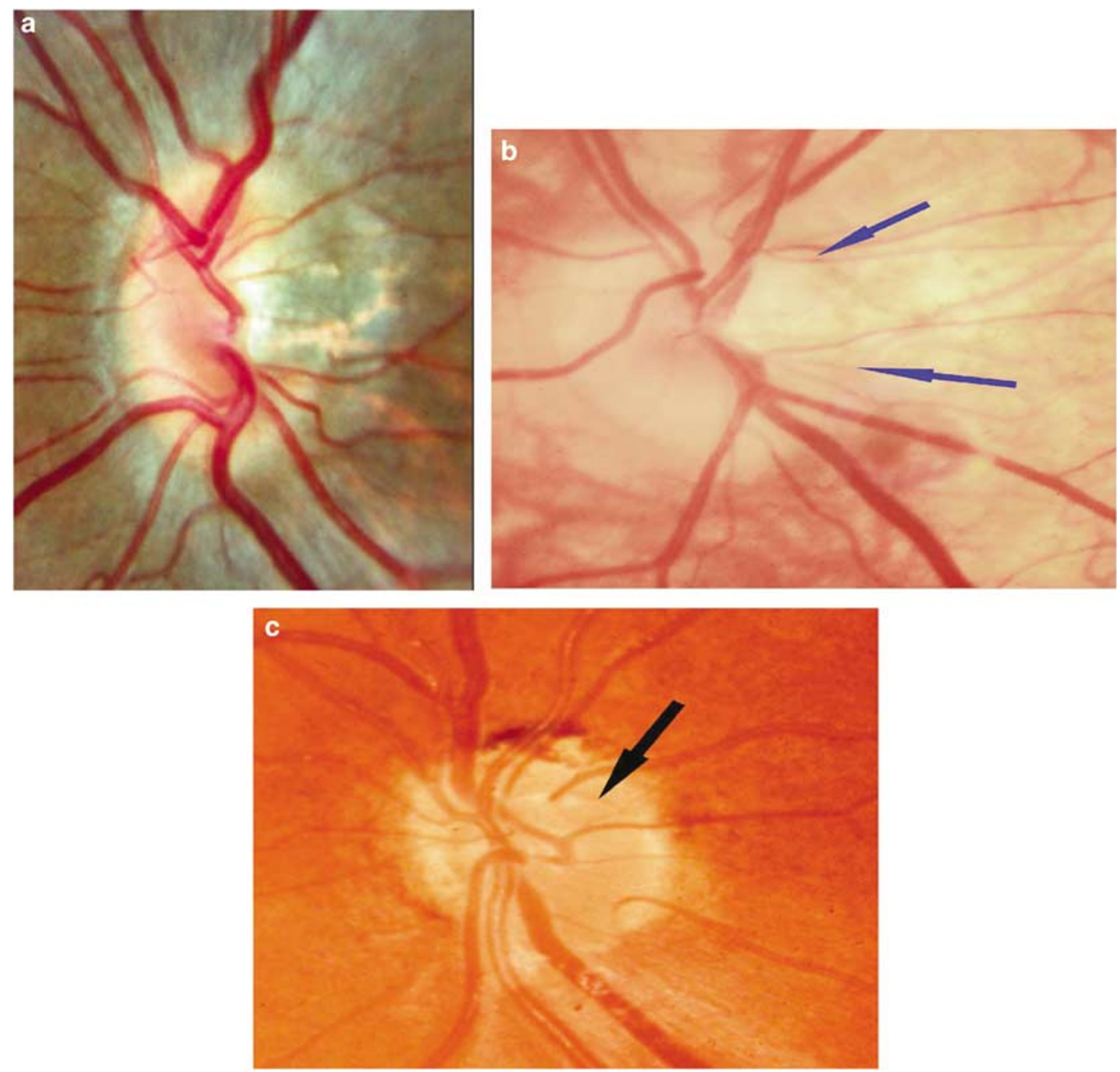

Figure 16 Segmental ONH. (a) Left eye. The visual acuity was 20/200 corrected (-6.0 D) in this eye with hypoplasia of the temporal quadrant. Illustration by courtesy of Dr Howard Friedman. (b) The temporal segment, between the arrows, is hypoplastic, associated with an acuity of about $6 / 60$ corrected in this child with perinatal hypoxia. The right eye was normal. (c) Hypoplasia of the superior segment of the optic disc in a person who went to an optometrist for a routine eye test before a driving test. There was an inferior half field defect in this left eye, but the acuity was 20/20. The right eye was normal. Illustration by courtesy of Dr Phil Aitken. See Figure 22.

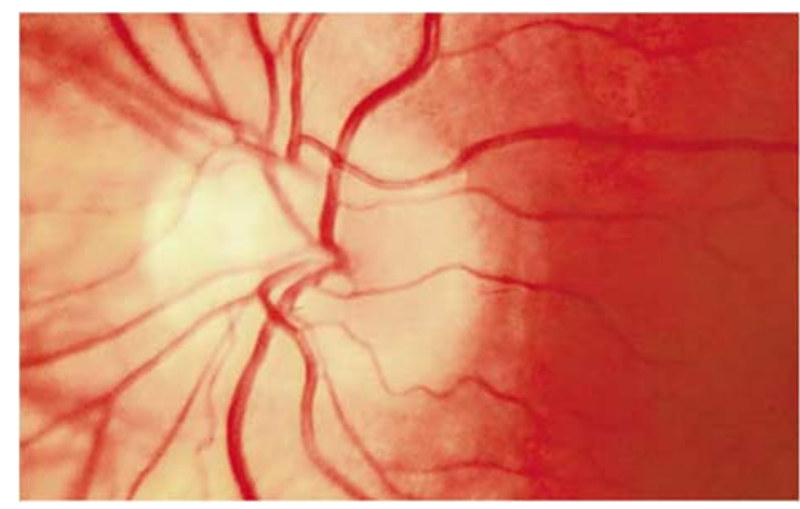

Figure 17 Situs Inversus. Left eye, with the macula towards the right of the picture. The retinal vessels emerge nasally before curving round to form the arcades. Vision was normal. optic discs that were of normal overall size, but may still be hypoplastic by trans-synaptic degeneration, which gives rise to cupping (Figure 18). They suggested that any lesion giving rise to loss of RGC axons before the attainment of full size by the optic disc (they say 1 year) should be referred to as hypoplasia, not atrophy. Acuity may be normal despite quite large cups and field defects, ${ }^{153}$ but may still cause concern about the possibility of glaucoma. ${ }^{152}$ However, the history of prematurity, the nonglaucomatous fields (where field studies are available), the round cup eccentric towards the temporal or supero-temporal parts of the optic disc, and the normal intraocular pressure should be enough to distinguish the common PVL-associated cup from the unusual glaucoma. ${ }^{152}$ 

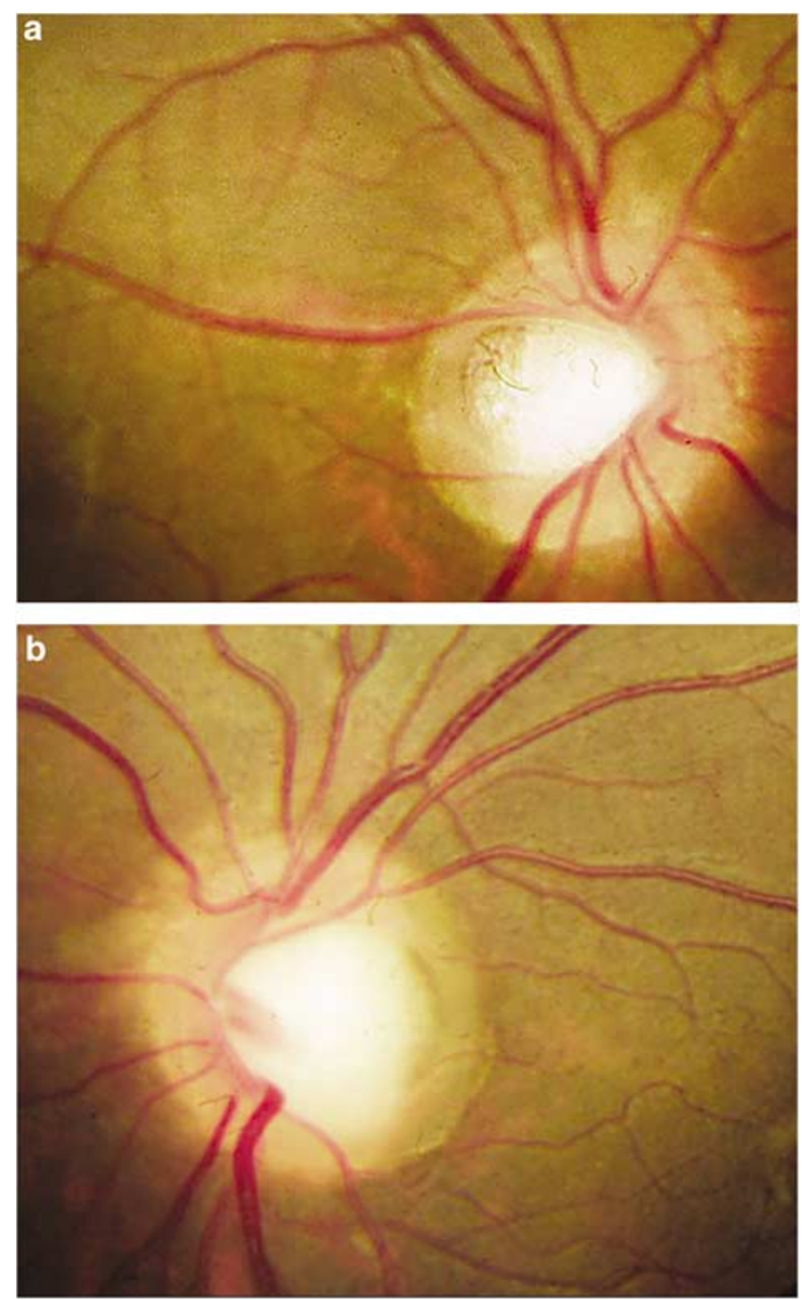

Figure $18 \mathrm{ONH}$ in a child with PVL en ex-premature babies: (a) right eye, (b) left eye. The optic discs are normal-sized but cupped and bilaterally symmetrical. Such cases may, when testable, have ill-defined, often inferior field defects. This has been described as a form of 'axial' ONH in a fully formed optic disc, resulting from trans-synaptic degeneration across the lateral geniculate body, following a primary lesion in the optic radiations. ${ }^{151}$

The timing of $\mathrm{ONH}$ and the site of the causative lesion: The timing of this 'insult' has been of some interest, most authors agreeing that the abnormality has occurred by the tenth week of gestation. ${ }^{154}$ The retina does not clearly appear until 30 days and therefore the 'insult' must occur after this time. It is, however, difficult to extrapolate from the various pieces of evidence and it is only possible to conclude that the defect, when severe, occurs early in prenatal development. However there are recent suggestions that some cases occur late in pregnancy and even postnatally. ${ }^{118,123,151}$ The development of the optic disc continues after birth, albeit at a much reduced rate; hence, using the definition of $\mathrm{ONH}$ as an abnormality of the optic disc with a reduced RGC population that occurs
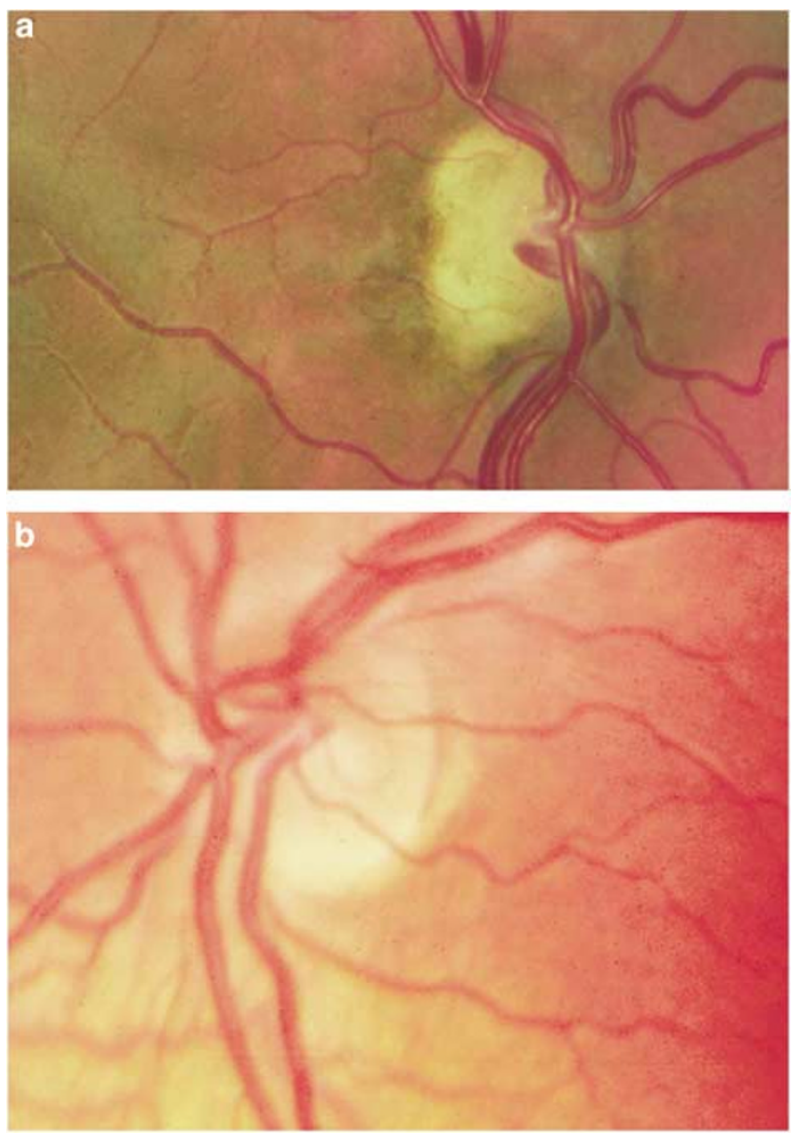

Figure 19 Anterior visual pathway tumours and optic disc anomalies. ${ }^{158}$ (a) This 5-year-old child had had a shunt for hydrocephalus at 2 months of age but never developed good vision; she had a suprasellar space-occupying lesion on CT scanning. Both optic discs were hypoplastic: the right eye, illustrated here, had a 'figure of eight' configuration, suggesting more marked hypoplasia of the portions of the optic disc associated with the nerve fibres subserving the temporal visual field. (b) Left tilted optic disc associated with an ipsilateral optic glioma.

before the full development of the optic disc, it is possible to include a wide variety of cases. It must be, however, that very small hypoplastic discs (ie Figure 10) must result from an early insult and subtle hypoplasia (ie Figure 16b), where the optic disc size is overall roughly normal, from later insult.

The occurrence of specific patterns of hypoplasia results from local defects throughout the central nervous system; ${ }^{149}$ the site of the 'insult' in $\mathrm{ONH}$ is reflected in the pattern of disc hypoplasia. For instance, the appearance of segmental optic disc hypoplasia related to a macular coloboma means the site of the injury is in the eye, while optic disc hypoplasia of a 'figure of eight' shape (Figure 19a) in patients with suprasellar tumour suggests a chiasmal site. The optic disc hypoplasia therefore results from an early injury at any site in the developing nervous system. 
ON anomalies with tumours of the anterior visual pathways: The occurrence of suprasellar and other related tumours in patients with tilted optic discs has been considered fortuitous and it must be rare enough not to warrant neuro-imaging for that reason alone (but neuroimaging is usually performed for other reasons anyway). There are a few case reports and small series of cases where $\mathrm{ONH}$ or tilted discs have been associated with a tumour in the region of the chiasm: giant aneurysm, ${ }^{96}$ teratoma, ${ }^{155}$ small teratoma, ${ }^{156}$ germinoma, ${ }^{157}$ adenoma, ${ }^{157}$ optic glioma, ${ }^{158}$ craniopharyngioma, ${ }^{158}$ and arachnoid cyst. ${ }^{159}$ Many of these tumours may have a developmental or prenatal origin, suggesting that the abnormality of development that gave rise to the tumour, or the tumour itself, may be causally linked to the ON under-development (Figure 19): some may be entirely coincidental. ${ }^{160}$

Homonymous hemioptic hypoplasia: Retro-chiasmal lesions may give rise to a pattern of $\mathrm{ONH}$ by transsynaptic degeneration across the lateral geniculate body. Hoyt and Rios-Montenegros ${ }^{140}$ described a case in which trans-synaptic degeneration from a cerebral lesion gave rise to a characteristic pattern of optic disc hypoplasia which reflected the field defect that the lesion caused; they called this appearance homonymous hemioptic hypoplasia (Figure 20). The ipsilateral optic tract may be shown to be missing on MRI scanning. ${ }^{161}$ It may be mixed with direct damage to the developing visual system occurring, in the same patient, with transsynaptic degeneration. ${ }^{162}$

Pathology: A few pathological studies have been carried out: ${ }^{86,122,124,154,163-165}$ most showed an absence of or a reduction in the numbers of ganglion cells and their axons, small optic discs and nerves with abnormal glial tissue. Other parts of the neuroretina are usually normal and, apart from incidental anomalies, the eyes were otherwise normal.

Pathogenesis: The wide variety of associated central neurodevelopmental anomalies might lead one to conclude that the loss of ganglion cells was secondary to a retrograde degeneration along the visual pathway and the cases of homonymous hemioptic hypoplasia are a dramatic example of this. However, the occurrence of unilateral optic disc hypoplasia and of partial or segmental optic disc hypoplasia must mean that the site in those cases is anterior in the visual system. ${ }^{149}$ Optic disc hypoplasia is therefore probably a nonspecific abnormality resulting from a prenatal insult to any part of the visual system. A relationship between optic disc hypoplasia and colobomas has been suggested. ${ }^{166}$

Family history and genetics: Familial cases have been described, ${ }^{12,167-171}$ but they are rare and not all necessarily genetic, and in the absence of a recurrent environmental cause (such as drugs or alcohol) a very low recurrence risk can be given. Associations with gene mutations, especially of HESX1, are recorded: ${ }^{75,76,79,172}$ some of these have been in siblings, and especially if associated with consanguinity, or if two siblings are affected, the condition may be inherited as an autosomal recessive trait. Optic disc hypoplasia, and its systemic associations should, however, mostly be regarded as sporadic in their occurrence. An exception to this rule is in aniridia, which has a familial occurrence and is associated with optic disc hypoplasia, ${ }^{173}$ although usually the optic disc is small rather than truly hypoplastic.

Associated anomalies and aetiological factors: Although optic disc hypoplasia may appear to be the result of an isolated event, it occurs in association with certain risk factors and with other abnormalities (Figure 21). Young maternal age, ${ }^{21,116,117,174-176}$ first babies, dose-dependant maternal smoking ${ }^{21}$ and preterm birth may be significant risk factors. ${ }^{21}$ There may be an association with inner city areas, linked to unemployment and teenage pregnancy. ${ }^{176}$

Associations with hydranencephaly, ${ }^{164,165,177}$ anencephaly, ${ }^{154,163,165}$ aniridia, ${ }^{140,173}$ congenital hemiplegia with hemianopia, ${ }^{140}$ porencephaly, ${ }^{178}$ cerebral atrophy ${ }^{179}$ and colpocephaly ${ }^{180}$ have been described. Quinine taken by the mother as an abortifacient early in pregnancy has been associated with $\mathrm{ONH}$ in the infant, ${ }^{181}$ as has maternal anticonvulsant, ${ }^{182}$ serotonin reuptake inhibitors, ${ }^{21,134}$ LSD $^{183}$ and crack cocaine. ${ }^{184}$ Viral infection has been implicated in cattle. ${ }^{185} \mathrm{ONH}$ frequently occurs in children with the foetal alcohol syndrome. ${ }^{186-188}$ Anecdotally, there seems to be considerable variation in the association of alcohol ingestion and $\mathrm{ONH}$, with studies from the USA and Scandinavia showing a close association, but those from other countries, where alcohol intake is just as high, nationally, showing a lower correlation. ${ }^{134}$

$\mathrm{ONH}$ in maternal diabetes: Diabetic mothers have babies with a higher incidence of neurological anomalies, including optic disc hypoplasia. ${ }^{133,189-191}$ In children of diabetic mothers, the superior half of the disc may be most affected, the so-called superior segmental $\mathrm{ONH}^{190}$ SSONH or 'topless' optic discs (Figure 22). It is usually accompanied by a relatively mild visual defect and the signs may be subtle. In all, $9 \%$ of the children of diabetic mothers are at risk for this condition. ${ }^{192}$ Female sex, short gestation time, low birth weight, and poor maternal diabetes control are additional risk factors. They may occur without maternal diabetes. ${ }^{193}$ SSONH has been described in identical twins, ${ }^{170}$ but there are no pathogenetic clues other than the fact that RGC axon guidance proteins (ie EphB) are found in the superior 
a

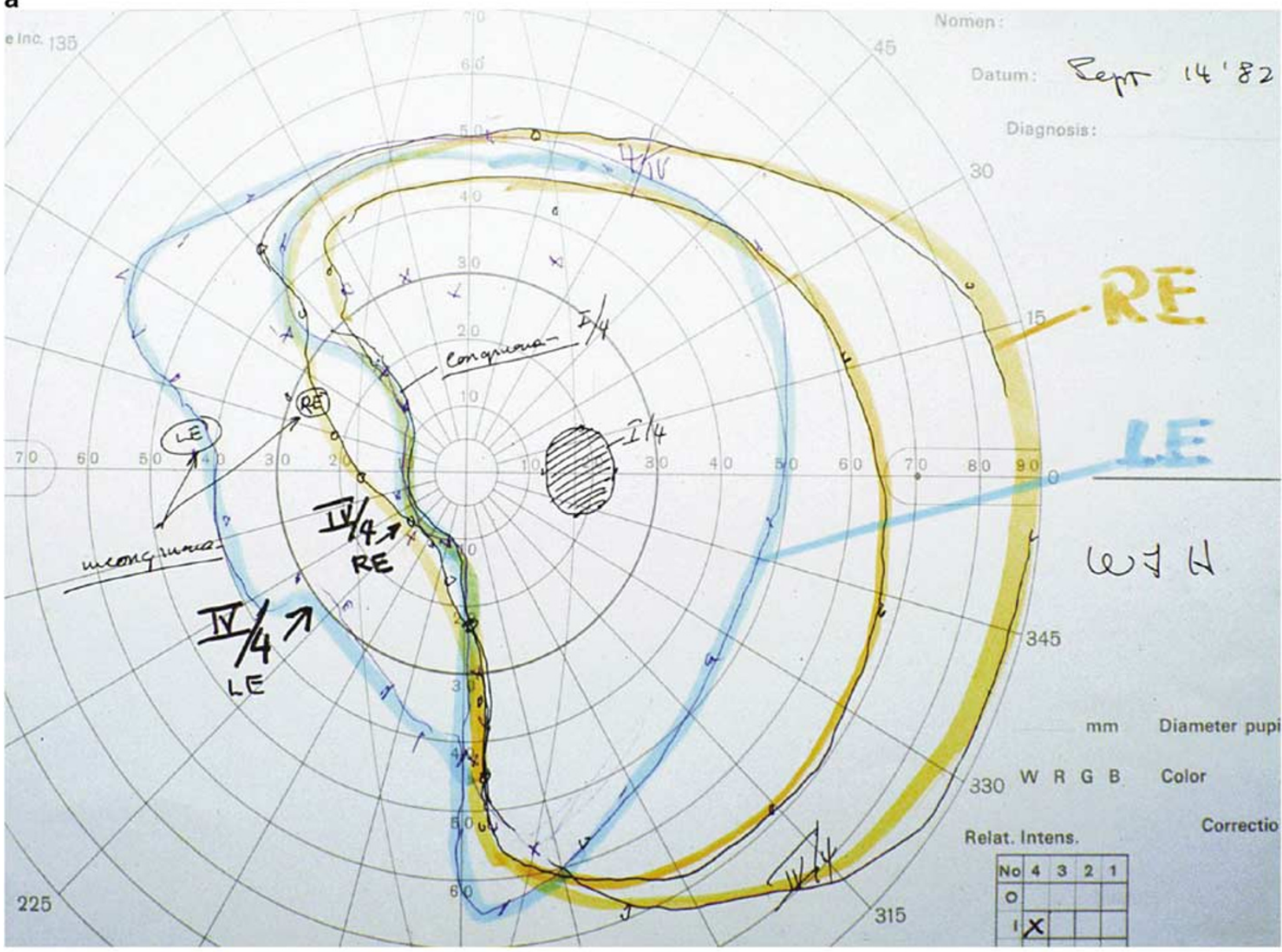

b
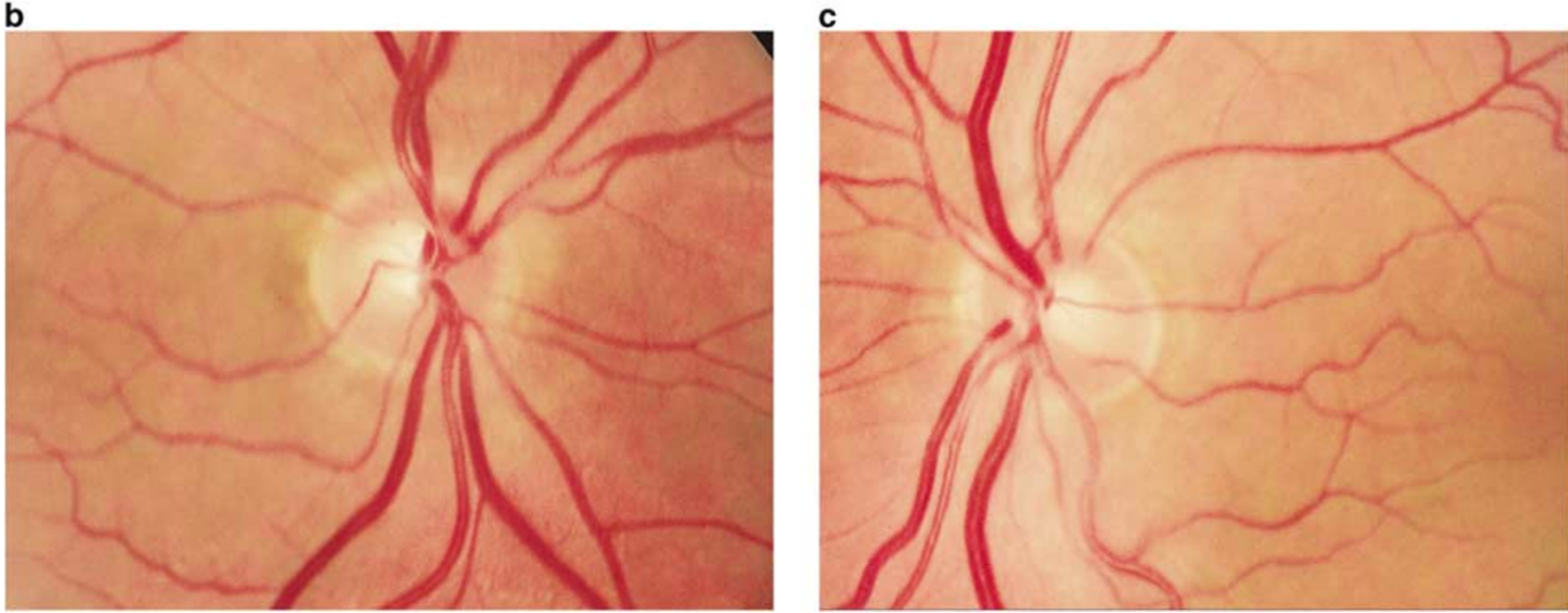

Figure 20 Homonymous hemioptic hypoplasia. ${ }^{140}$ By the kind permission of Professor WF Hoyt. (a) The patient had an incidentally discovered congenital left homonymous hemianopia. This visual field study was performed by Professor WF Hoyt. (b) The right eye shows only a very subtle, all-round, diffuse loss of retinal nerve fibres. (c) The left optic disc is slightly small and shows selective preservation of the superior and inferior nerve fibre bundles, which subserve the intact nasal visual field. The left optic disc is slightly more oval-shaped than that of the right eye (b), and has more of a ring around it.

(dorsal) retina; their absence in mice lets the developing axons stray away from their normally tightly fasciculated paths to the optic disc. ${ }^{40}$
Neuroimaging: Where available, MRI is the modality of choice in $\mathrm{ONH}^{142}$ and should be performed in all affected children because of the association with brain and 


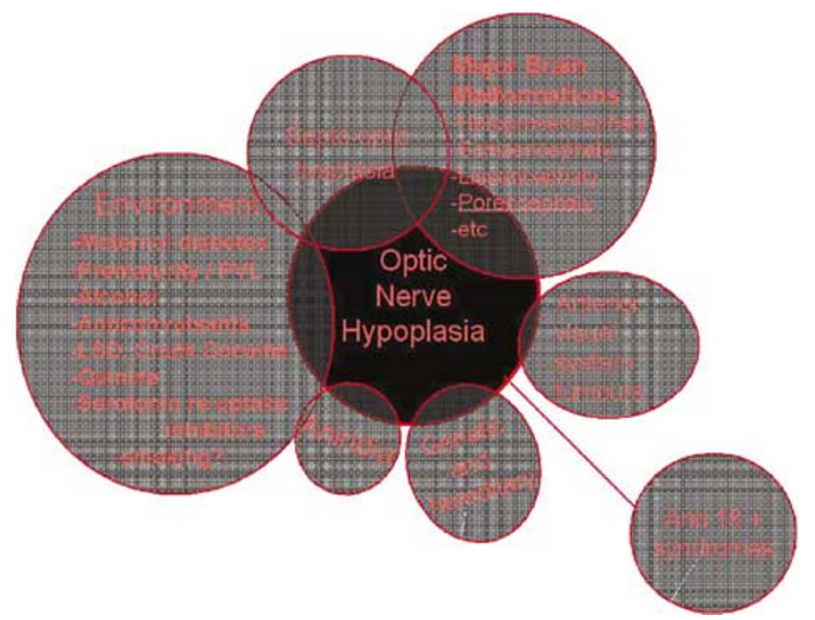

Figure 21 Aetiological and associated features of $\mathrm{ONH}$.

endocrine defects. MRI allows the anterior visual pathways to be delineated and sagittal Tl-weighted MR images can show attenuation of the ON. ${ }^{142}$ Combined with clinical information, such as body habitus and with or without hypothalamic-pituitary axis abnormalities, it is a powerful diagnostic tool ${ }^{134}$ which can be vital in predicting endocrine problems.

Coronal TI-weighted MR shows focal thinning of the chiasm corresponding to the hypoplastic nerve in unilateral and bilateral cases. ${ }^{142}$

MRI may show a wide variety of structural abnormalities of the cerebral hemispheres and commisures, hypothalamus, visual system, the pituitary body and stalk, so septo-optic dysplasia cannot be thought of as a single condition. ${ }^{194}$ Hemispheric abnormalities occur in nearly half of patients with $\mathrm{ONH}$, including migration anomalies (polymicrogyria, schizencephaly, heterotopia), intrauterine or perinatal hemispheric injury (periventricular leukomalacia, encephalomalacia). ${ }^{194}$ Posterior pituitary ectopia is not uncommon. ${ }^{194}$ Normally, the posterior pituitary gland appears bright on TI-weighted images, ${ }^{194,195}$ but in posterior pituitary ectopia (Figure 23), there is absence of the normal posterior pituitary and its infundibulum and an ectopic posterior pituitary bright spot at the tuber cinereum. ${ }^{194,195}$ This suggests anterior pituitary hormone deficiency, whereas the cerebral hemispheric abnormalities and thinning or agenesis of the corpus callosum suggest neurodevelopmental deficits in both bilateral and unilateral cases: ${ }^{194}$ absence of the septum pellucidum alone is not endocrinologically significant, ${ }^{134,196}$ and if the septum pellucidum and the hypothalamic-pituitary axis are both normal it is unlikely that there will be any endocrine disturbance. ${ }^{134}$

Septo-optic dysplasia and associated brain malformations: The first clear description of the syndrome of absence of the septum pellucidum and $\mathrm{ONH}$ (Figure 24) was by De
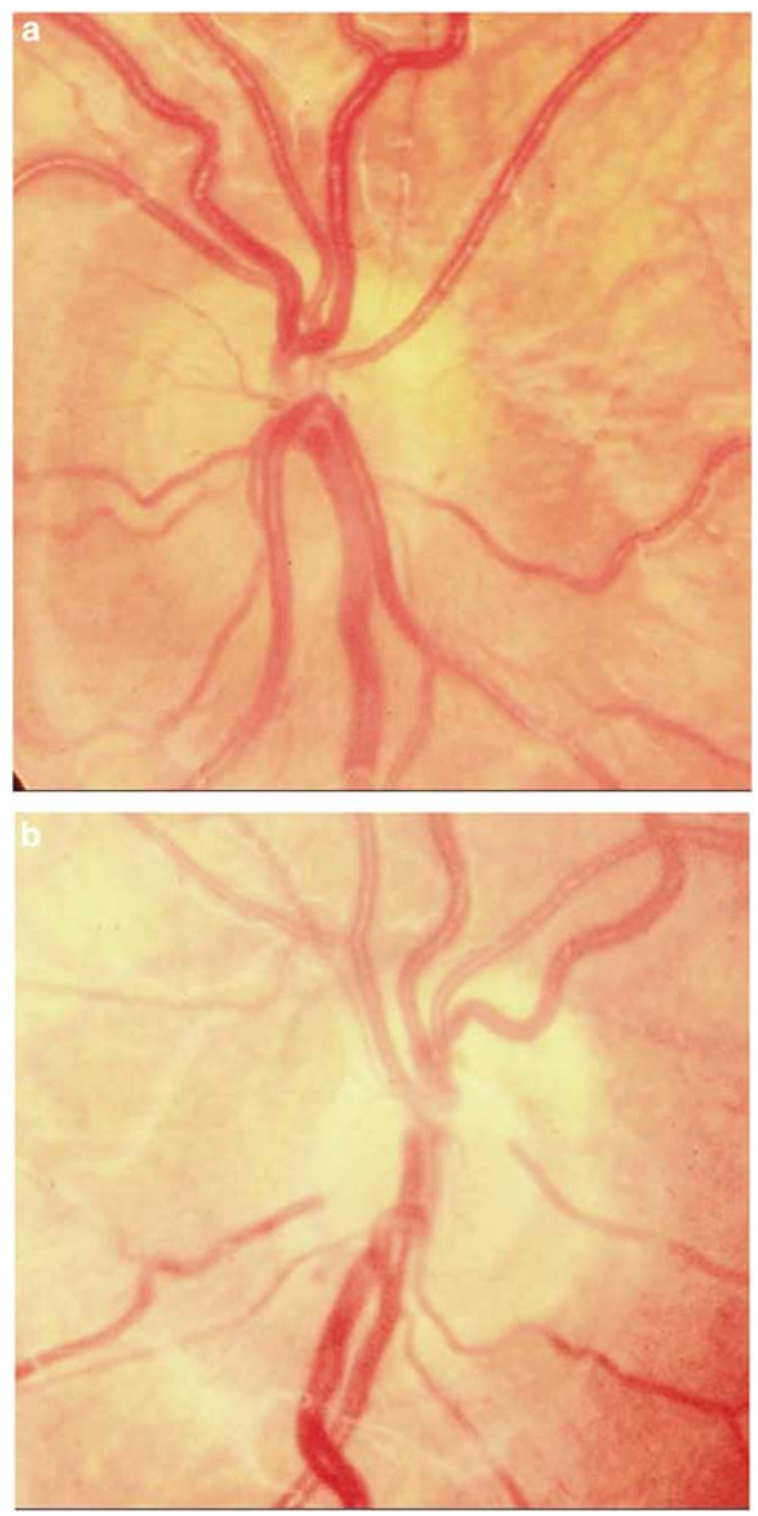

Figure 22 Superior segmental hypoplasia. In about $10 \%$ of children of diabetic mothers, the superior half of the optic disc may be hypoplastic, the so-called superior segmental $\mathrm{ONH}^{190}$ or 'topless' optic discs. Girls are affected more frequently than boys, the babies are often premature, the vision is often relatively good and the mother's diabetes is often brittle. (a) Right eye; (b) left eye.

Morsier. ${ }^{197}$ Hoyt et al ${ }^{198}$ were the first to clearly demonstrate hypopituitarism in patients with septo-optic dysplasia and since then a variety of hormonal defects have been described, ranging from isolated growth hormone, adrenocorticotrophic, or antidiuretic hormone deficiency to panhypopituitarism. ${ }^{199-205}$ Evaluation of these endocrine disturbances is now the province of the paediatric endocrine specialist. Hypothyroidism may be the most common significant abnormality, ${ }^{206,207}$ but there is such variation in incidence in the various studies and 


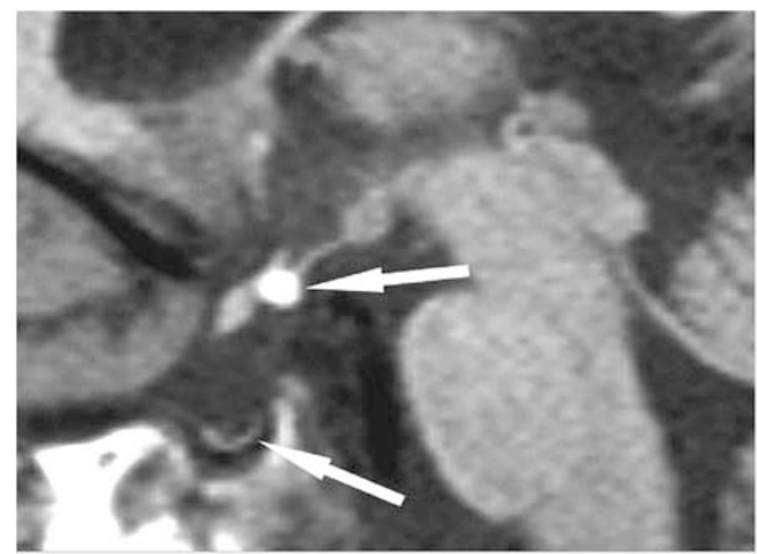

Figure 23 Sagittal MRI of the hypothalamic-pituitary axis. The pituitary (lower arrow) is small and scalloped. There is absence of the normal posterior pituitary and stalk in and above the pituitary fossa, and an ectopic posterior pituitary bright spot where the infundibulum normally is (upper arrow). MRI image courtesy of Dr Mehul Dattani.

the possibility of minimal abnormalities in multiple hormones should be taken into account in all cases.

Abnormalities of the septum pellucidum alone may affect spatial task performances, ${ }^{208}$ but most affected children with only a septum pellucidum defect are healthy and grow well. ${ }^{209}$ Hypoplasia or absence of the corpus callosum is commonly associated.

Pathology in a case ${ }^{191}$ showed an absent posterior lobe of the pituitary gland, with an abnormal hypothalamus. The pituitary defects may occur in optic disc hypoplasia even without evidence of absence of the septum pellucidum. ${ }^{205}$

While many patients have ONH with only an abnormal septum pellucidum or pituitary stalk ${ }^{210}$ and hypopituitarism, a spectrum of brain malformations vary

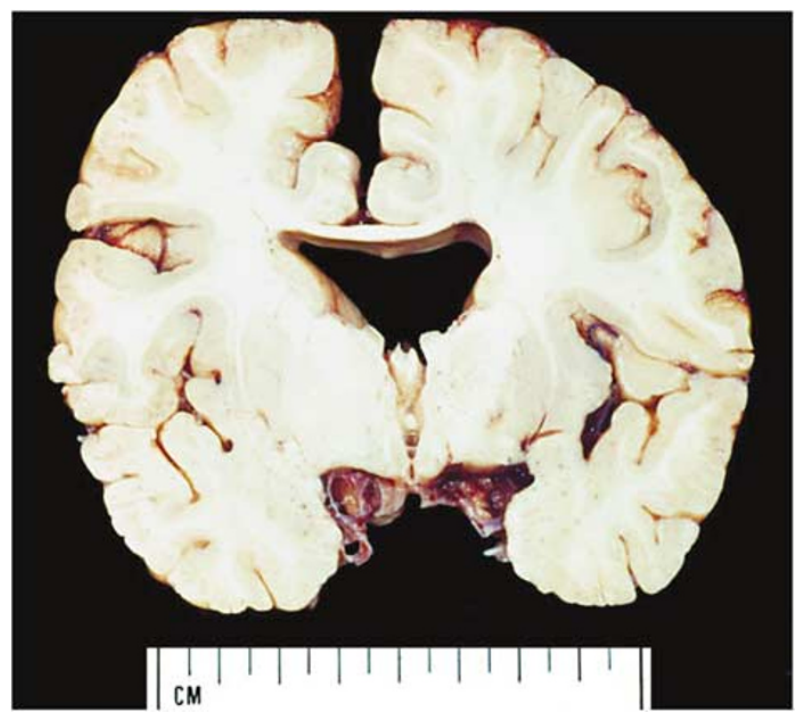

Figure 24 Septo-optic dysplasia. Brain of a child who died after becoming dehydrated in a hot climate, showing the absence of the septum pellucidum and hypoplastic corpus callosum.

widely in severity, ${ }^{211}$ including holoprosencephaly and other major developmental brain abnormalities. In holoprosencephaly, a variable midline facial defect is associated with a single cerebral ventricle, and absence of the corpus callosum and septum pellucidum; there is also a wide variety of other brain defects causing similar problems. ${ }^{189,202,212,213}$

Pathological studies in holoprosencephaly have shown absence of the olfactory apparatus, which forms a link with Kallmann's syndrome ${ }^{214}$ in which gonadotrophin, growth hormone, and antidiuretic hormone deficiency and anosmia are associated with forebrain abnormalities (Figure 25). ${ }^{215}$

Features of $\mathrm{ONH}$ with endocrine dysfunction

Endocrine deficiency

Multiple Pituitary dwarfism ${ }^{198}$

Growth hormone (GHD) ${ }^{19}$ Thyroid hormone (THD) ${ }^{206}$ Corticotrophin

Anti-diuretic hormone

Symptom or presentation

Variable incidence

Puberty

Neonatal hypoglycaemia ${ }^{134,207,217}$

Neonatal jaundice

Obesity

Evolving endocrinopathy $207,216,225$ Sudden death ${ }^{218}$

\section{Comment}

Commonest when both hypothalamic-pituitary axis and septum pellucidum are abnormal. ${ }^{134}$ Probably most frequent

May not be clinically apparent for 3 years $+{ }^{216}$

Suggested by neonatal jaundice? ${ }^{206,217}$

At risk of sudden death ${ }^{218}$ (Figure 25) or acute adrenal deficiency post-operatively. ${ }^{219}$ Provocative tests may be necessary to diagnose

Suggested by absence of intrasellar or ectopic pituitary bright signal ${ }^{220}$ or absent infundibulum

\section{Comment}

$13-65 \%$ 134,194,195,211,216,220-222

May be early or late 223

Probably have corticotrophin deficiency

Suggests thyroid hormone deficiency ${ }^{206,217}$

May be associated with THD, GHD or excess steroid replacement, but usually not associated with endocrinopathy ${ }^{224}$

Long-term monitoring for growth even if normal early

Corticotrophin deficiency, DI, hypothalamic defect 


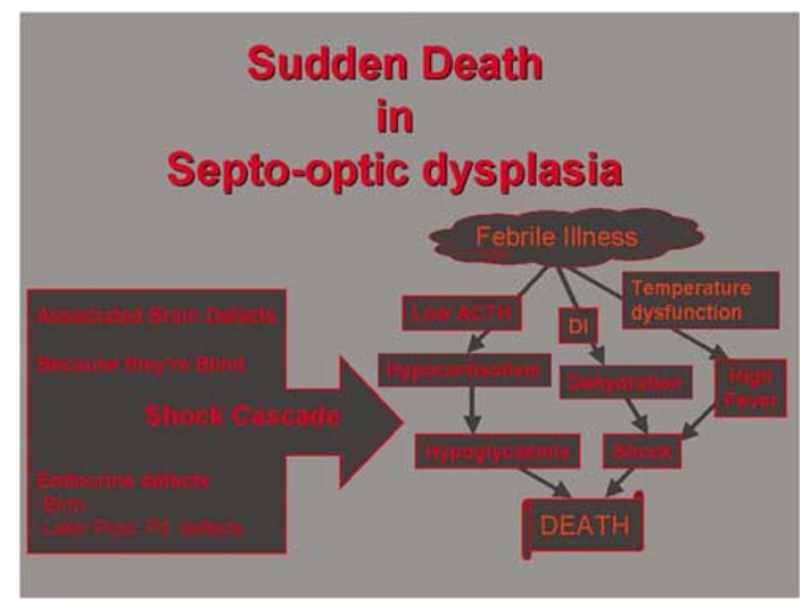

Figure 25 Children with septo-optic nerve dysplasia are at risk for dying in infancy for several reasons. In all, $10 \%$ of blind infants die for various reasons, ${ }^{22}$ children with brain malformations are at greater risk and they have endocrine defects. As they may have hypothalamic abnormalities and endocrine defects, they may suffer a shock cascade if challenged by what would otherwise be an easily overcome fever. ${ }^{218}$

\section{Management of children with $\mathrm{ONH}$}

1 All cases should have an endocrinological assessment on presentation with follow-up as determined by the result of the endocrinological and neuroimaging studies. Unilateral optic disc hypoplasia should be investigated in the same way as bilateral cases. If sophisticated endocrinology is not available, monitoring height and weight annually until at least puberty is recommended.

2 Infants with optic disc hypoplasia should have neuroimaging studies to confirm or exclude associated cerebral malformations and other defects; those with abnormalities need to be under the care of a paediatrician, endocrinologist or both. MRI is the modality of choice: it may reveal anomalies in the hypothalamic-pituitary axis which may predict hormonal problems, and the finding on MRI of structural brain abnormalities may be a good predictor of neurological problems. ${ }^{194}$ Whether or not MRI abnormalities are found, weight and height must be monitored annually ${ }^{206}$ - this is probably the responsibility of the child's paediatrician or primary care physician. Where MRI is not available, CT is indicated in infancy, because there are fewer developmental milestones to guide the clinician as to whether there are developmental problems.

After 2 years of age, if the child's growth and development is normal, it is not essential to perform advanced neuro-radiology, but it is still necessary to measure height and weight regularly. ${ }^{217}$
3 Developmental delay may occur in patients with optic disc hypoplasia without structural brain defects, at least with the neuro-imaging of the 1980s. ${ }^{206}$

4 In looking for optic disc hypoplasia, a direct ophthalmoscopic examination is preferable, because it is essential to use the high magnification of that instrument to adequately see the optic disc details. An examination under anaesthetic should rarely be necessary.

5 A child with optic disc hypoplasia may also be amblyopic in that eye; the vision may be improved by timely optical correction, where necessary, and vigorous occlusion. ${ }^{110}$

6 The condition is not inherited but familial clusters may occur, due to environmental reasons or, rarely, consanguinity or other hereditary factors. The HESX1 gene shows variable penetrance.

\section{Chiasmal maldevelopment}

\section{Achiasmia}

Unilateral $^{101}$ and bilateral ${ }^{106,226,227}$ ONA may produce an asymmetrical or absent chiasm. ${ }^{101}$ Bilateral

anophthalmos is usually associated with absence of ONs, chiasm, and lateral geniculate bodies. ${ }^{156,228,229}$ Sometimes there are remnants of the $\mathrm{ON}$ and chiasm, and studies in man and mouse led to speculation ${ }^{226}$ that the blood vessels or changes in time and location of the physiologic cell necrosis (apoptosis) may be important (Figure 26).

Williams et $a l^{58}$ identified an autosomal recessive mutation in Belgian sheepdogs that eliminates the optic chiasm. These mutant dogs have either see-saw or atypical congenital idiopathic type nystagmus. ${ }^{58,230,231}$

Absence of the human chiasm was first reported in recent times by Apkarian et al, ${ }^{232,233}$ coining the term 'Non-decussating retinal-fugal fibre syndrome'. Apkarian did her historical research well and found from reading Meckel ${ }^{234}$ and Henle ${ }^{235}$ herself, and from Polyak $^{27}$ that Vesalius had described two cases. She went on to translate Vesalius ${ }^{236}$ from the Latin and found that he described a third case, with a congenitally absent chiasm, in a patient with normal vision and no diplopia.

Although suspected on clinical grounds and strongly indicated by electrophysiology, MRI studies are the best way of confirming the diagnosis (Figures 27 and 28). ${ }^{237}$

Achiasmic patients can have good, ${ }^{238,239}$ and sometimes remarkably normal vision despite MRI- and fMRI-proven functional achiasmia. ${ }^{240}$ In the case studied by Victor $e t a l,{ }^{240}$ vernier acuity was normal, and there was no evidence for the confounding of visual information between the overlapping ipsi-lateral and contralateral representations. Contrast sensitivity and velocity judgments were abnormal, but their dependence 
on the orientation and velocity of the targets suggests that this deficit was due to ocular instabilities, rather than the mis-wiring. There were no asymmetries in performance of visual search, visual naming, or illusory contour perception. fMRI analysis of the latter two tasks under monocular viewing conditions indicated extensive bilateral activation of striate and prestriate areas, suggesting efficient transfer of information between the hemispheres.
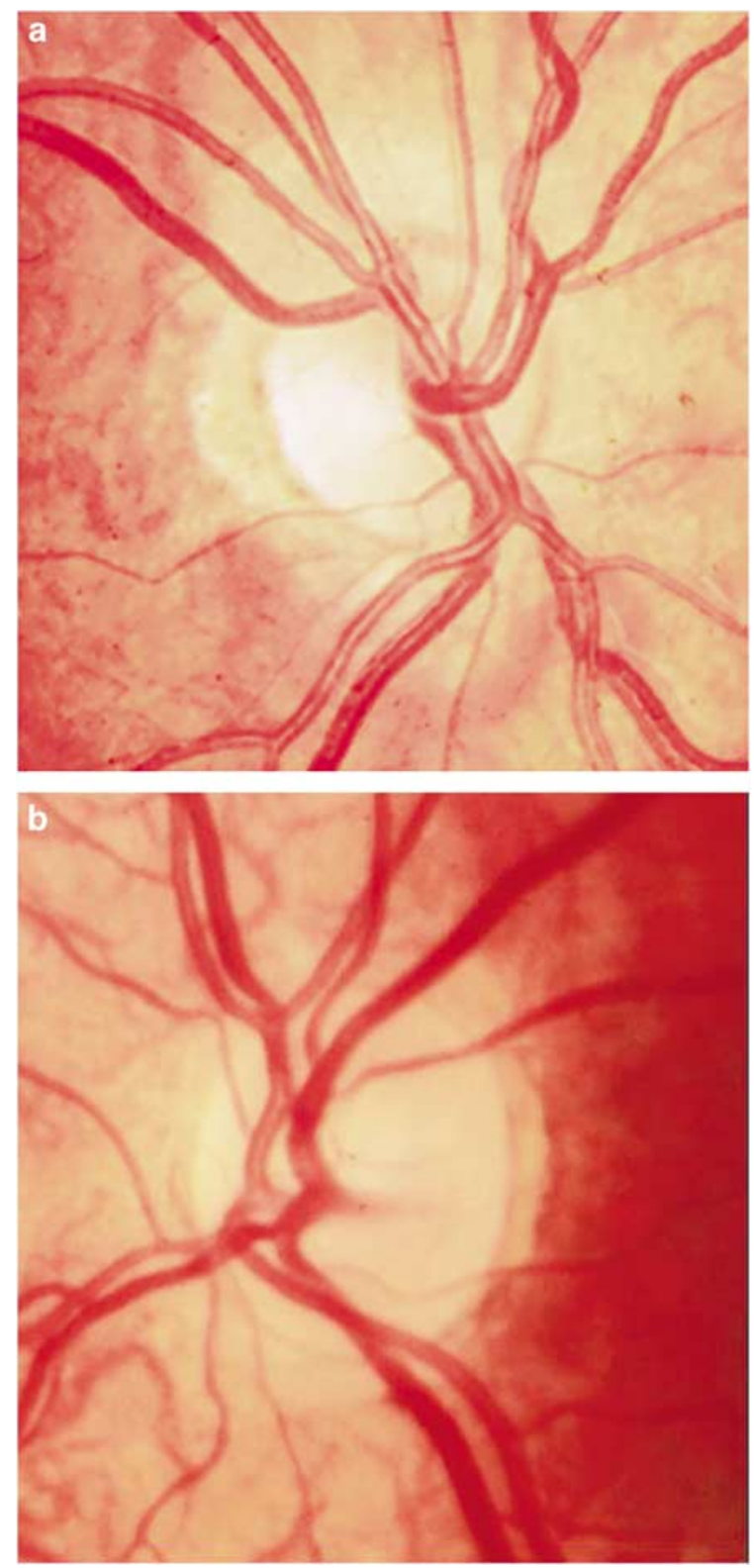

Figure 26 Achiasmia. There is a wide spectrum of optic disc abnormalities in achiasmia from normal to substantial dysplasia. $^{239}$ The right eye of this patient (a) shows subtle optic disc hypoplasia with atrophy, the left optic disc (b) is normal.
A variety of fundus findings have been described (Figures 26-28), from normal optic discs, ${ }^{241}$ through optic disc hypoplasia to dysplastic optic discs.

Early-onset see-saw nystagmus is a frequent feature. $230,233,238,239,242$

Abnormalities of a number of genes ${ }^{243}$ and guidance proteins ${ }^{77}$ may be associated with chiasmal maldevelopment.

\section{Maldevelopments of the optic tracts}

Isolated absence of the optic tracts, almost certainly prenatal in origin were described ${ }^{161}$ in two asymptomatic patients who had MRI studies which showed unilateral optic tract absence with ipsilateral band atrophy and contralateral pallor but not associated with structural disc changes, the brain and lateral geniculate body were normal. Mostly, optic tract hypoplasia is associated with other visual system and cerebral abnormalities. ${ }^{244}$ It may be associated with widespread maldevelopment of the anterior visual system. ${ }^{156}$

\section{Acknowledgements}

Professor William F Hoyt ignited my passion for neuro-ophthalmology; Professor Otto Wolff stimulated and encouraged my interest in paediatric ophthalmology, and showed me how to listen, relate to, and be honest with child patients and their parents. Michael Sanders was a wonderful colleague over many years, being supportive in the good as well as the bad times, and a good friend. Darius Hildebrand helped with translation of German and and Alex Ionnides of classical Greek. David Sretavan and Jan Provis gave advice on aspects of ON development and helped with illustrations. Jane Leitch helped with research into Bowman's life and times and, particularly, Carole Reeves did inspirational work on the history of the ON. ${ }^{23}$ My colleagues, Isabelle Russell-Eggitt and Ken Nischal, put up with the vagaries of my work pattern, while I was preparing this work and Katharine Barr helped with the early stages of the manuscript. Many thanks are due to the Medical illustration department at Great Ormond Street Hospital, Jeremy Naylor and Nick Geddes in particular, for all their help with the illustrations for this and numerous other works. Dr Mehul Dattani kindly supplied Figure 23 and read the manuscript with an endocrinological eye. Creig Hoyt, who has been a longtime friend, took over the major burden of book editing from me in a crucial time of writing this manuscript and gave helpful criticism. Most of all, my gratitude, love, and thanks go to Anna, my lifelong love and friend. 

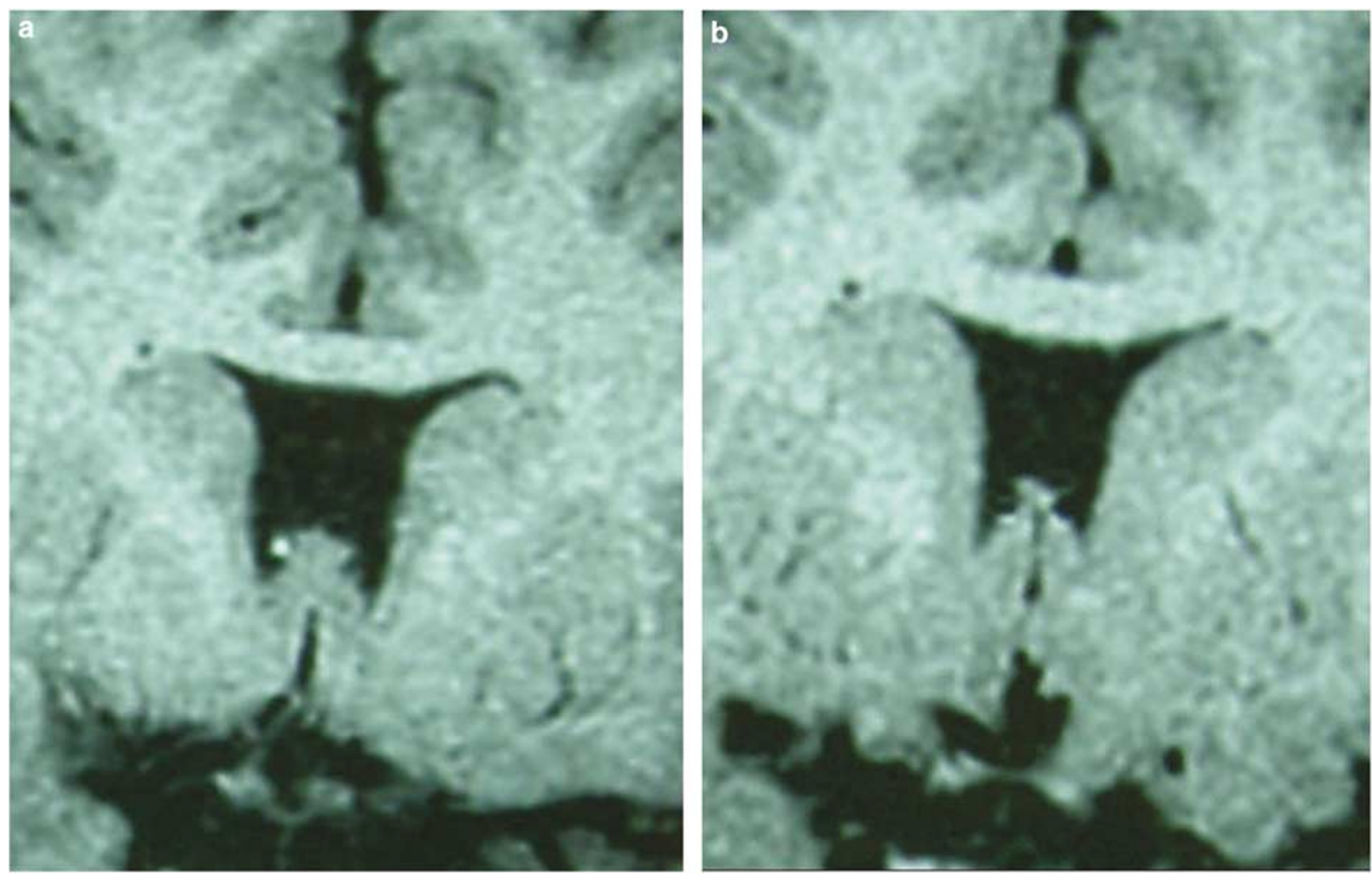

Figure 27 Adjacent slices of MRI scans of a patient with achiasmia, crossed asymmetry on VEPs, ONH and developmental delay. The ONs and tracts were small and the chiasm is extremely hypoplastic (arrow). The septum pellucidum is absent.
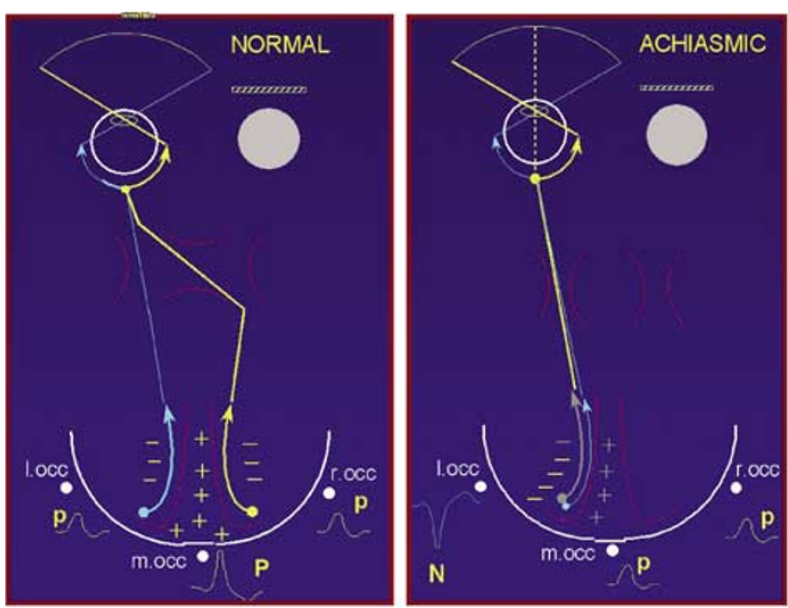

Figure 28 VEPs in a normal subject (left) show an even distribution across the occiput when the left eye is stimulated, the amplitude is largest at the mid-occipital electrode. In achiasmia (right), the distribution when the left eye is stimulated is asymmetrical, reflecting the preponderance of the ipsilateral projection. Illustrations by courtesy of Dr Dorothy Thompson.

\section{Afterword}

'May I say, on the part of older men, that we look eagerly and hopefully towards the younger to instruct us in new paths, to correct our many inadvertences and errors, and to be our pioneers towards a brighter future ${ }^{245}$

\section{References}

1 Burdon-Sanderson J, Hulke JW. The Collected Papers of Sir William Bowman. Harrison: London, 1892.

2 Todd RB, Bowman W. The Physiological Anatomy and Physiology of Man. John Parker: London, 1845, pp 1-448 (vol 1), 10660 (vol 2).

3 Jaeger E. Ueber Staar und Staaroperationen. Verlag von L.W. Seidel: Wien, 1854, p 103, Figure XXXIV.

4 von Graefe A. Vorläufige Notize über das Wesen des Glaucoms. Arch Ophthalmol 1854; 1: 371-382.

5 Frost WA. The Fundud Oculi, 1st ed. Young J Pentland: Edinburgh \& London, 1896, Plate 2, Figure 14

6 Liebreich R. Atlas of Ophthalmoscopy, 2nd ed. Churchill: London, 1870, Plate 2, Figure 3.

7 Newman W. Congenital blindness in two sisters-absence of optic disc and retinal vessels. Roy London Ophthal Hospital Rep 1864; 6: 202-204.

8 Boyce DC. Hypoplasia of the optic nerve. Am J Ophthalmol 1941; 34: 888-889.

9 Cords R. Einseitige kleinheit der papille. Klin $\mathrm{Mbl}$ Augenheilkd 1923; 71: 414-418.

10 Edwards WC, Layden WE. Optic nerve hypoplasia. Am J Ophthalmol 1970; 70: 950-959.

11 Jerome B, Forster JW. Congenital hypoplasia (partial aplasia) of the optic nerve. Arch Ophthalmol 1948; 89: 669-672.

12 Missiroli G. Una nuova sindrome congenita a carattere falungliare, ipoplasia del nervo ottico e emianopsia binasale. Boll Occul 1947; 26: 683-691. 
13 Ridley H. Aplasia of the optic nerves. Br J Ophthalmol 1938; 22: 669-671.

14 Scheie HG, Adler FH. Aplasia of the optic nerve. Arch Ophthalmol 1941; 26: 61-70.

15 Somerville F. Uniocular aplasia of the optic nerve. $\mathrm{Br} J$ Ophthalmol 1962; 46: 51-55.

16 Schwartz O. Ein Fall von mangelhafter Bildung(Hypoplasie) beider Sehnerven. von Graefe's Arch Ophthalmol 1915; 90: 326-328.

17 Hoyt C, Good W. Do we really understand the difference between optic nerve hypoplasia and atrophy? Eye 1992; 6 201-204.

18 Jan JE, Robinson GC, Kinnis C, MacLeod PJM. Blindness due to optic atrophy and hypoplasia in children: an epidemiological study (1944-74). Dev Med Child Neurol 1977; 19: 353-363.

19 Brodsky MC. Congenital optic disk anomalies. Surv Ophthalmol 1994; 39: 89-112.

20 Blohme J, Tornqvist K. Visual impairment in Swedish children. III. Diagnoses. Acta Ophthalmol Scand 1997; 75: 681-687.

21 Tornqvist K, Ericsson A, Kallen B. Optic nerve hypoplasia: risk factors and epidemiology. Acta Ophthalmol Scand 2002 80: 300-304.

22 Rahi JS, Cable N. Severe visual impairment and blindness in children in the UK. Lancet 2003; 362: 1359-1365.

23 Reeves C, Taylor DSI. A history of the optic nerve and its diseases. Eye 2004; 18: 1096-1109.

24 Nutton V. In: Conrad LI, Neve M, Nutton V, Porter R, Wear A (eds) The Western Medical Tradition: 800 BC to AD 1800. Cambridge University Press: Cambridge, 1995, p 66.

25 Vesalius A. On the Fabric of the Human Body (De humani corporis fabrica). Book IV: The Nerves. Translated by William Frank Richardson with John Burd Carman. Norman Publishing: Novato, 2002.

26 Theiss $\mathrm{P}$, Grusser OJ. Vision and cognition in the natural philosophy of Albert the Great (Albertus Magnus). Doc Ophthalmol 1994; 86: 123-151.

27 Polyak S. The Vertebrate Visual System. University of Chicago Press: Chicago, IL, 1957.

28 Taylor J(C). Mechanismus oder neue abhandlung von der kunstl. Zusammensetz.des menslichen Auges. Frankfurt, 1750.

29 Marquardt T. Transcriptional control of neuronal diversification in the retina. Prog Retin Eye Res 2003; 22: 567-577.

30 Tropepe V, Coles BL, Chiasson BJ, Horsford DJ, Elia AJ, McInnes RR et al. Retinal stem cells in the adult mammalian eye. Science 2000; 287: 2032-2036.

31 Boulton M, Albon J. Stem cells in the eye. Int J Biochem Cell Biol 2004; 36: 643-657.

32 Oster SF, Sretavan DW. Connecting the eye to the brain: the molecular basis of ganglion cell axon guidance. $\mathrm{Br} \mathrm{J}$ Ophthalmol 2003; 87: 639-645.

33 Tessier-Lavigne M, Goodman CS. The molecular biology of axon guidance. Science 1996; 274: 1123-1133.

34 Yu TW, Bargmann CI. Dynamic regulation of axon guidance. Nat Neurosci 2001; 4(Suppl): 1169-1176.

35 van Horck FPG, Weinl C, Holt CE. Retinal axon guidance: novel mechanisms for steering. Curr Opin Neurobiol 2004; 14: $1-6$.

36 Oster SF, Deiner M, Birgbauer E, Sretavan DW. Ganglion cell axon pathfinding in the retina and optic nerve. Semin Cell Dev Biol 2004; 15: 125-136.
37 Deiner MS, Kennedy TE, Fazeli A, Serafini T, TessierLavigne M, Sretavan DW. Netrin-1 and DCC mediate axon guidance locally at the optic disc: loss of function leads to optic nerve hypoplasia. Neuron 1997; 19: 575-589.

38 Deiner MS, Sretavan DW. Altered midline axon pathways and ectopic neurons in the developing hypothalamus of netrin-1- and DCC-deficient mice. J Neurosci 1999; 19: 9900-9912.

39 Birgbauer E, Oster SF, Severin CG, Sretavan DW. Retinal axon growth cones respond to EphB extracellular domains as inhibitory axon guidance cues. Development 2001; 128: 3041-3048.

40 Birgbauer E, Cowan CA, Sretavan DW, Henkemeyer M. Kinase independent function of EphB receptors in retinal axon pathfinding to the optic disc from dorsal but not ventral retina. Development 2000; 127: 1231-1241.

41 Nakamura F, Kalb RG, Strittmatter SM. Molecular basis of semaphorin-mediated axon guidance. J Neurobiol 2000; 44: 219-229.

42 Raper JA. Semaphorins and their receptors in vertebrates and invertebrates. Curr Opin Neurobiol 2000; 10: 88-94.

43 Oster SF, Bodeker MO, He F, Sretavan DW. Invariant Sema5A inhibition serves an ensheathing function during optic nerve development. Development 2003; 130: 775-784.

44 Goldberg GL, Vargas ME, Oster SF, Sretavan DW, Barres BA. An oligodendrocyte lineage-specific semaphorin, Seme5A, inhibits axon growth by retinal ganglion cells. Neuron 2004 (in press).

45 Wilkinson DG. Topographic mapping: organising by repulsion and competition? Curr Biol 2000; 10: 447-451.

46 Ming GL, Song HJ, Berninger B, Holt CE, Tessier-Lavigne M, Poo MM. cAMP-dependent growth cone guidance by netrin-1. Neuron 1997; 19: 1225-1235.

47 Stein E, Tessier-Lavigne M. Hierarchical organization of guidance receptors: silencing of netrin attraction by slit through a Robo/DCC receptor complex. Science 2001; 291: 1928-1938.

48 Georges P, Madigan MC, Provis JM. Apoptosis during development of the human retina: relationship to foveal development and retinal synaptogenesis. J Comp Neurol 1999; 413: 198-208.

49 Provis JM, van Driel D, Billson FA, Russell P. Development of the human retina: patterns of cell distribution and redistribution in the ganglion cell layer. J Comp Neurol 1985; 233: 429-451.

50 Provis JM, van Driel D, Billson FA, Russell P. Human fetal optic nerve: overproduction and elimination of retinal axons during development. J Comp Neurol 1985; 238: 92-100.

51 Sturrock RR. Changes in the number of axons in the human embryonic optic nerve from 8 to 18 weeks gestation. J Hirnforsch 1987; 28: 649-652.

52 Naskar R, Dreyer EB. New horizons in neuroprotection. Surv Ophthalmol 2001; 45(Suppl 3): S250-S255.

53 Ozanics V, Jakobiec F In: Jakobiec F (ed) Ocular Anatomy, Embryology and Teratology. Harper \& Row: Philadelphia, 1982, pp 11-96.

54 Sturrock RR. An electron microscopic study of macrophages in the meninges of the human embryonic optic nerve. J Anat 1988; 157: 145-151. 
55 Provis JM. Patterns of cell death in the ganglion cell layer of the human fetal retina. J Comp Neurol 1987; 259: 237-246.

56 Penfold PL, Provis JM. Cell death in the development of the human retina: phagocytosis of pyknotic and apoptotic bodies by retinal cells. Graefes Arch Clin Exp Ophthalmol 1986; 224: 549-553.

57 Provis JM, Billson FA, Russell P. Ganglion cell topography in human fetal retinae. Invest Ophthalmol Vis Sci 1983; 24: 1316-1320

58 Williams RW, Hogan D, Garraghty PE. Target recognition and visual maps in the thalamus of achiasmatic dogs. Nature 1994; 367: 637-639.

59 Fukuda Y, Sawai H, Watanabe M, Wakakuwa K, Morigiwa K. Nasotemporal overlap of crossed and uncrossed retinal ganglion cell projections in the Japanese monkey (Macaca fuscata). I Neurosci 1989; 9: 2353-2373.

60 Jeffery G. Architecture of the optic chiasm and the mechanisms that sculpt its development. Physiol Rev 2001; 81: 1393-1414.

61 Rasband K, Hardy M, Chien CB. Generating X: formation of the optic chiasm. Neuron 2003; 39: 885-888.

62 Williams SE, Mason CA, Herrera E. The optic chiasm as a midline choice point. Curr Opin Neurobiol 2004; 14: 1-10.

63 Inatani M, Irie F, Plump AS, Tessier-Lavigne M, Yamaguchi Y. Mammalian brain morphogenesis and midline axon guidance require heparan sulfate. Science 2003; 302: 1044-1046.

64 Plump AS, Erskine L, Sabatier C, Brose K, Epstein CJ, Goodman CS et al. Slit1 and Slit2 cooperate to prevent premature midline crossing of retinal axons in the mouse visual system. Neuron 2002; 33: 219-232.

65 Erskine L, Williams SE, Brose K, Kidd T, Rachel RA, Goodman CS et al. Retinal ganglion cell axon guidance in the mouse optic chiasm: expression and function of robos and slits. J Neurosci 2000; 20: 4975-4982.

66 Herrera E, Brown L, Aruga J, Rachel RA, Dolen G, Mikoshiba $\mathrm{K}$ et al. Zic2 patterns binocular vision by specifying the uncrossed retinal projection. Cell 2003; 114: 545-557.

67 Lin L, Chan SO. Perturbation of CD44 function affects chiasmatic routing of retinal axons in brain slice preparations of the mouse retinofugal pathway. Eur J Neurosci 2003; 17: 2299-2312.

68 Williams SE, Mann F, Erskine L, Sakurai T, Wei S, Rossi DJ et al. Ephrin-B2 and EphB1 mediate retinal axon divergence at the optic chiasm. Neuron 2003; 39: 919-935.

69 Cooper ML, Pettigrew JD. The decussation of the retinothalamic pathway in the cat, with a note on the major meridians of the cat's eye. J Comp Neurol 1979; 187: 285-311.

70 Barber AN. RGNMRH. Development of the visual pathway; optic chiasm. Arch Ophthalmol 1954; 52: 447-456

71 Sretavan DW, Reichardt LF. Time-lapse video analysis of retinal ganglion cell axon pathfinding at the mammalian optic chiasm: growth cone guidance using intrinsic chiasm cues. Neuron 1993; 10: 761-777.

72 Sretavan DW. Pathfinding at the mammalian optic chiasm. Curr Opin Neurobiol 1993; 3: 45-52.

73 Sretavan DW, Pure E, Siegel MW, Reichardt LF. Disruption of retinal axon ingrowth by ablation of embryonic mouse optic chiasm neurons. Science 1995; 269: 98-101.

74 Sretavan DW. Specific routing of retinal ganglion cell axons at the mammalian optic chiasm during embryonic development. J Neurosci 1990; 10: 1995-2007.
75 Tajima T, Hattorri T, Nakajima T, Okuhara K, Sato K, Abe S et al. Sporadic heterozygous frameshift mutation of HESX1 causing pituitary and optic nerve hypoplasia and combined pituitary hormone deficiency in a Japanese patient. J Clin Endocrinol Metab 2003; 88: 45-50.

76 Brickman JM, Clements M, Tyrell R, McNay D, Woods K, Warner $\mathrm{J}$ et al. Molecular effects of novel mutations in Hesx1/HESX1 associated with human pituitary disorders. Development 2001; 128: 5189-5199.

77 Kruger K, Tam AS, Lu C, Sretavan DW. Retinal ganglion cell axon progression from the optic chiasm to initiate optic tract development requires cell autonomous function of GAP-43. J Neurosci 1998; 18: 5692-5705.

78 Zhang F, Lu C, Severin C, Sretavan DW. GAP-43 mediates retinal axon interaction with lateral diencephalon cells during optic tract formation. Development 2000; 127 969-980.

79 Dattani MT, Martinez-Barbera JP, Thomas PQ, Brickman JM, Gupta R, Martensson IL et al. Mutations in the homeobox gene HESX1/Hesx1 associated with septo-optic dysplasia in human and mouse. Nat Genet 1998; 19: 125-133.

80 Carvalho LR, Woods KS, Mendonca BB, Marcal N, Zamparini AL, Stifani $S$ et al. A homozygous mutation in HESX1 is associated with evolving hypopituitarism due to impaired repressor-corepressor interaction. J Clin Invest 2003; 112: 1192-1201.

81 Cohen RN, Cohen LE, Botero D, Yu C, Sagar A, Jurkiewicz $\mathrm{M}$ et al. Enhanced repression by HESX1 as a cause of hypopituitarism and septooptic dysplasia. J Clin Endocrinol Metab 2003; 88: 4832-4839.

82 Azuma N, Yamaguchi Y, Handa H, Tadokoro K, Asaka A, Kawase E et al. Mutations of the PAX6 gene detected in patients with a variety of optic-nerve malformations. Am J Hum Genet 2003; 72: 1565-1570.

83 Newman W. Congenital blindness in two sisters-absence of optic disc and retinal vessels. Roy London Ophthal Hospital Rep 1864; 6: 202-204.

84 Little LE, Whitmore PV, Wells TW. Aplasia of the optic nerve. J Pediatr Ophthalmol 1976; 13: 84-88.

85 Weiter JJ, McLean IW, Zimmerman LE. Aplasia of the optic nerve and disc. Am J Ophthalmol 1977; 83: 569-576.

86 Hotchkiss ML, Green WR. Optic nerve aplasia and hypoplasia. J Pediat Ophthalmol Strabismus 1970; 16: 225-240.

87 Mann I. Developmental Abnormalities of the Eye, 2nd ed. British Medical Association: London, 1957, p 126.

88 von Szily A. Die Ontogenese der Idiotypischen(erbildichen) Spaltbildungen des Auges, des Mikrophthalmus und der Orbitalcysten. Z Anat Entwicklungsgesch 1924; 74: 1-48.

89 Warfel JH. A case of unilateral degenerative anophthalmia. Am J Ophthalmol 1961; 51: 698-701.

90 Oster SF, Deiner M, Birgbauer E, Sretavan DW. Ganglion cell axon pathfinding in the retina and optic nerve. Semin Cell Dev Biol 2004; 15: 125-136.

91 Brière W. Monsieur le Dr. Observations Cliniques.Obs VI. Absence des papilles, cécité absolue. Ann D'Oculistique 1877; LXXVII: 41-42.

92 Magnus H. Zur Casuistik der angeborenen SehnervenMissbildungen. Klin Mbl Augenheilkd 1884; 2: 85-87.

93 von Meisner M. Ein Colobomder Alderhaut und Netzhaut mit Aplasie des Sehnerven. Albrecht von Graefe's Arch Ophthalmol 1911; 49: 309-328. 
94 Young JH. Rare ocular developmental anomalies in association with congenital and acquired blindness. $\mathrm{Br} \mathrm{J}$ Ophthalmol 1940; 24: 597-610.

95 Renelt P. Beitrag zur echten Papillenaplasie. Albrecht Von Graefes Arch Klin Exp Ophthalmol 1972; 184: 94-98.

96 Hoff J, Winestock D, Hoyt WF. Giant suprasellar aneurysm associated with optic stalk agenesis and unilateral anophthalmos. Case report. J Neurosurg 1975; 43: 495-498.

97 Yanoff M, Balian Rorke L, Allman MI. Bilateral optic system aplasia with relatively normal eyes. Arch Ophthalmol 1978; 96: 97-101.

98 Ginsberg J, Bove KE, Cuesta MG. Aplasia of the optic nerve with aniridia. Ann Ophthalmol 1980; 12: 433-439.

99 Storm RL, PeBenito R. Bilateral optic nerve aplasia associated with hydranencephaly. Ann Ophthalmol 1984; 16 988-992.

100 Barry DR. Aplasia of the optic nerves. Int Ophthalmol 1985; 7: 235-242.

101 Margo CE, Hamed LM, Fang E, Dawson WW. Optic nerve aplasia. Arch Ophthalmol 1992; 110: 1610-1613.

102 Blanco R, Salvador F, Galan A, Gil-Gilbernau JJ. Aplasia of the optic nerve: a report of three cases. J Pediatr Ophthalmol Strabismus 1992; 29: 228-231.

103 Peiffer Jr RL, Bouldin TW, Huffines WD, Sulik KA. Ocular malformations associated with agnathia: a case report. J Craniofac Genet Dev Biol 1992; 12: 55-60.

104 Howard MA, Thompson JT, Howard RO. Aplasia of the optic nerve. Trans Am Ophthalmol Soc 1993; 91: 267-276.

105 Lee BL, Bateman JB, Schwartz SD. Posterior segment neovascularization associated with optic nerve aplasia. Am J Ophthalmol 1996; 122: 131-133.

106 Scott IU, Warman R, Altman N. Bilateral aplasia of the optic nerves, chiasm, and tracts in an otherwise healthy infant. Am J Ophthalmol 1997; 124: 409-410.

107 Pieramici DJ, Gonzalez C, Raja SC. Choroidal neovascularisation associated with aplasia of the optic nerve. Am J Ophthalmol 2001; 132: 439-440.

108 Brodsky MC, Atreides SP, Fowlkes JL, Sundin OH. Optic nerve aplasia in an infant with congenital hypopituitarism and posterior pituitary ectopia. Arch Ophthalmol 2004; 122 125-126.

109 Davis GU, Schoch JP. Septo-optic dysplasia associated with see-saw nystagmus. Arch Ophthalmol 1975; 93: 137-139.

110 Kushner BJ. Functional amblyopia associated with abnormalities of the optic nerve. Arch Ophthalmol 1984; 102 683-685.

111 Zeki SM. Optic nerve hypoplasia and astigmatism: a new association. Br J Ophthalmol 1990; 74: 297-299.

112 Archer SM. Amblyopia? J Am Assoc Pediatr Ophthalmol Strabismus 2000; 4: 257.

113 Lempert P. Optic nerve hypoplasia and small eyes in presumed amblyopia. Offic J Am Assoc Pediatr Ophthalmol Strabismus 2000; 4: 258-266.

114 Lempert P. Optic nerve hypoplasia diagnosis should be confirmed by accurate measurements. [letter; comment]. Arch Ophthalmol 1998; 116: 831-832.

115 Zion V. Optic nerve hypoplasia. Ophthal Semin 1976; 1: 171-196.

116 Elster AB, McAnarney ER. Maternal age re: septo-optic dysplasia. J Pediatr 1979; 94: 162

117 Purdy F, Friend JCM. Maternal factors in SOD (letter). J Pediatr 1979; 95: 661.
118 Hellström A. Optic nerve morphology may reveal adverse events during prenatal and perinatal life-digital image analysis. Surv Ophthalmol 2000; 44: S63-S73.

119 Walton DS, Robb RM. Optic nerve hypoplasia - a report of 20 cases. Arch Ophthalmol 1970; 84: 572-578.

120 Hellström A, Wiklund LM, Svensson E. The clinical and morphologic spectrum of optic nerve hypoplasia. J Am Assoc Pediatr Ophthalmol Strabismus 1999; 3: 212-220.

121 Manor RS, Korczyn AD. Retinal red-free light photographs in two congenital conditions. Ophthalmologica 1976; 173: 119-127.

122 Whinery RD, Blodi FC. Hypoplasia of the optic nerve: a clinical and histopathologic correlation. Trans Am Acad Ophthalmol Otol 1963; 67: 733-738.

123 Frisen L, Holmegaard L. Spectrum of optic nerve hypoplasia. Br J Ophthalmol 1978; 62: 7-15.

124 Mosier MA, Lieberman MF, Green WR, Knox DL. Hypoplasia of the optic nerve. Arch Ophthalmol 1978; 96: 1437-1442.

125 Alvarez E, Wakakura M, Khan Z, Dulton GN. The discmacula distance to disc-diameter ratio: a new test for confirming optic nerve hypoplasia in young children. I Pediatr Ophthalmol Strabismus 1988; 25: 151-156.

126 Zeki S, Dudgeon J, Dutton G. Reappraisal of the ratio of disc to macula/disc diameter in optic nerve hypoplasia. $\mathrm{Br}$ J Ophthalmol 1991; 75: 538-541.

127 Hellström A, Wiklund LM, Svensson E. Diagnostic value of magnetic resonance imaging and planimetric measurement of optic disc size in confirming optic nerve hypoplasia. J Am Assoc Pediatr Ophthalmol Strabismus 1999; 3: 104-108.

128 Romano PE. Simple photogrammetic diagnosis of optic nerve hypoplasia. Arch Ophthalmol 1989; 107 824-827.

129 Borchert M, McCulloch D, Rother C, Stout AV. Clinical assessment, optic disk measurements, and visual evoked potential in optic nerve hypoplasia. Am J Ophthalmol 1995; 120: $605-612$.

130 Unoki K, Ohba N, Hoyt WF. Optical coherence tomography of superior segmental optic hypoplasia. $\mathrm{Br}$ Ophthalmol JID - 0421041 2002; 86: 910-914.

131 Björk A, Laurell C-G, Laurell U. Bilateral optic nerve hypoplasia with normal visual acuity. Am J Ophthalmol 1978; 86: 524-529.

132 Gardner HB, Irvine AE. Optic nerve hypoplasia with good visual acuity. Arch Ophthalmol 1972; 88: 255-258.

133 Peterson RA, Walton DS. Optic nerve hypoplasia with good acuity and visual field defects: a study of infants in diabetic mothers. Arch Ophthalmol 1977; 95: 254-258.

134 Birkebæk NH, Patel L, Wright NB, Grigg JR, Sinha S, Hall $\mathrm{CM}$ et al. Optic nerve size evaluated by magnetic resonance imaging in children with optic nerve hypoplasia, multiple pituitary hormone deficiency, isolated growth hormone deficiency and idiopathic short stature. J Pediatr 2004; 145: 536-541.

135 Weiss AH, Kelly JP. Acuity, Ophthalmoscopy, and visually evoked potentials in the prediction of visual outcome in infants with bilateral optic nerve hypoplasia. J Am Assoc Pediatr Ophthalmol Strabismus 2003; 7: 108-115.

136 Weiss AH. Unilateral high myopia: optical components, associated factors, and visual outcomes. $\mathrm{Br}$ J Ophthalmol 2003; 87: 1025-1031. 
137 Buchanan TAS, Hoyt WF. Temporal visual field defects associated with nasal hypoplasia of the optic disc. $\mathrm{Br} \mathrm{J}$ Ophthalmol 1981; 65: 636-640.

138 Seeley RL, Smith JL. Visual field defects in optic nerve hypoplasia. Am J Ophthalmol 1971; 73: 882-889.

139 Ewald RA. Unilateral hypoplasia of the optic nerve: radiologic and electroretinographic findings. $A m \mathrm{~J}$ Ophthalmol 1967; 63: 763-767.

140 Hoyt WF, Rios-Montenegros EN, Berens MM, Eckelhoff RJ. Homonymous hemioptic hypoplasia. Fundoscopic features in standard and red-free illumination in three patients with congenital hemiplegia. Br J Ophthalmol 1972; 56: 537-545.

141 Sanders MD. CT scanning in diagnosis of orbital disease. J Roy Soc Med 1980; 73: 284-287.

142 Brodsky MC, Glasier C, Pollock S, Angtuago E. Optic nerve hypoplasia: identification by magnetic resonance imaging. Arch Ophthalmol 1990; 108: 1562-1568.

143 Dorrell D. The tilted disc. Br J Ophthalmol 1978; 62: 16-20.

144 Graham MV, Wakefield GJ. Bitemporal visual field defects associated with anomalies of the optic discs. $\mathrm{Br} \mathrm{J}$ Ophthalmol 1973; 57: 307-314.

145 Rucker CW. Bitemporal defects in the visual fields resulting from developmental anomalies of the optic discs. Arch Ophthalmol 1946; 35: 546-554.

146 Young SE, Walsh FB, Knox DL. The tilted disc syndrome. Am J Ophthalmol 1976; 82: 16-23.

147 Brazitikos P, Safran A, Simona F, Zulauf M. Threshold perimetry in the tilted disc syndrome. Arch Ophthalmol 1990; 108: 1698-1701.

148 Pinckers A, Lion F, Notting JGA. X-chromosomal recessive night-blindness and tilted disc anomaly. Ophthalmologica 1978; 176: 160-163.

149 Novakovic P, Taylor DSI, Hoyt WF. Localising patterns of optic nerve hypoplasia - retina to occipital lobe. $\mathrm{Br}$ Ophthalmol 1988; 72: 176-183.

150 Fuchs E. Beitrag zu den angenborenen Anomalien des schnerven. Graefe's Arch Ophthalmol 1882; 28: 139-169.

151 Jacobson L, Hellström A, Flodmark O. Large cups in normal-sized optic discs: A variant of optic nerve hypoplasia in children with periventricular leukomalacia. Arch Ophthalmol 1997; 115: 1263-1269.

152 Lee AG. Perinatal visual loss. Ophthalmology 2003; 110: 625.

153 Brodsky MC. Periventricular Leucomalacia. An intracranial cause of pseudoglaucomatous cupping. Arch Ophthalmol 2001; 119: 626-627.

154 Boniuk V, Ho PK. Ocular findings in anencephaly. Am J Ophthalmol 1979; 88: 613-617.

155 Lee JT, Hall TR, Bateman JB. Optic nerve hypoplasia secondary to intracranial teratoma. Am J Ophthalmol 1997; 124: 705-706

156 Recordon E, Griffiths GM. A case of primary bilateral anophthalmia. Br J Ophthalmol 1938; 22: 353-361.

157 Keane JR. Suprasellar tumours and incidental optic disc anomalies. Arch Ophthalmol 1977; 95: 2180-2183.

158 Taylor D. Congenital tumours of the anterior visual system with dysplasia of the optic discs. Br J Ophthalmol 1982; 66: 455-463.

159 Lyons C, Castano G, Jan JE, Sargent M. Optic nerve hypoplasia with intracranial arachnoid cyst. J AAPOS 2004; 8: 61-66.

160 Osher RH, Schatz NJ. A sinister association of the congenital tilted disc syndrome with chiasmal compression. In: Smith JL (ed) Neuro-ophthalmology Focus. Masson: New York, 1979, pp 117-123.

161 Margo CE, Hamed LM, McCarty J. Congenital optic tract syndrome. Arch Ophthalmol 1991; 109: 1120-1122.

162 Kupersmith MJ, Vargas M, Hoyt WF, Berenstein A. Optic tract atrophy with cerebral arteriovenous malformations: direct and transsynaptic degeneration. Neurology 1994; 44: 80-83.

163 Anderson SR, Bro-Rasmussen F, Tygstrup I. Anencephaly related to ocular development and malformation. Am J Ophthalmol 1972; 74: 967-975.

164 Manschot WA. Eye findings in hydranencephaly. Ophthalmologica 1971; 162: 151-159.

165 Manschot WA. In: Stanley Cant J (ed) The Optic Nerve. H Kimpton: London, 1972.

166 Brown GC. Optic nerve hypoplasia and colobomatous defects. J Pediatr Ophthalmol Strabismus 1982; 19: 90-93.

167 Benner JD, Preslan MW, Gratz E, Joslyn J, Schwartz M, Kelman S. Septo-optic dysplasia in two siblings. Am J Ophthalmol 1990; 109: 632-638.

168 Hackenbruch Y, Meerhoff E, Besio R, Cardoso H. Familial bilateral optic nerve hypoplasia. Am J Ophthalmol 1975; 79: 314-320.

169 Kytila J, Miettinen P. On bilateral aplasia of the optic nerve. Acta Ophthalmol 1961; 39: 416-419.

170 Brodsky MC, Schroeder GT, Ford R. Superior segmental optic hypoplasia in identical twins. J Clin Neuroophthalmol 1993; 13: 152-154.

171 Wales JK, Quarrell OW. Evidence for possible Mendelian inheritance of septo-optic dysplasia. Acta Paediatr 1996; 85: 391-392.

172 Birrell G, Lampe A, Richmond S, Bruce SN, Gecz J, Lower $\mathrm{K}$ et al. Borjeson-Forssman-Lehmann syndrome and multiple pituitary hormone deficiency. J Pediatr Endocrinol Metab 2003; 16: 1295-1300.

173 Layman PR, Anderson DR, Flynn JT. Frequent occurrence of hypoplastic optic discs in patients with aniridia. Am J Ophthalmol 1974; 77: 513-516.

174 Margalith D, Jan JE, McCormick AQ, Tze WJ, Lapointe J. Clinical spectrum of congenital optic nerve hypoplasia: review of 51 patients. Dev Med Child Neurol 1984; 26: 311-322.

175 Robinson GC, Conry RF. Maternal age and congenital optic nerve hypoplasia: a possible clue to etiology. Dev Med Child Neurol 1986; 28: 294-298.

176 Harrison E, Cairns DP, Lloyd IC, Wright N, Patel L, Hall $\mathrm{CM}$ et al. Occurrence of septo-optic dysplasia in the North-West of England: a geographical analysis. 2005 (in press).

177 Herman DC, Bartley GB, Bullock JD. Ophthalmic findings of hydranencephaly. J Pediatr Ophthalmol Strabismus 1988; 25: $106-112$

178 Greenfield PS, Wilcox LM, Weiter JJ. Hypoplasia of the optic nerve in association with porencephaly. J Pediatr Ophthalmol Strabismus 1980; 17: 75-78.

179 Rogers GL, Brown D, Gray I, Bremer D. Bilateral optic nerve hypoplasia associated with cerebral atrophy. J Pediatr Ophthalmol Strabismus 1981; 18: 18-22.

180 Garg BP. Colpocephaly. Arch Neurol 1982; 39: 243-246.

181 McKinna AJ. Quinine induced hypoplasia of the optic nerve. Canad J Ophthalmol 1966; 1: 261-265.

182 Hoyt CS, Billson FA. Maternal anticonvulsants and optic nerve hypoplasia. Br J Ophthalmol 1978; 62: 3-6. 
183 Chan T, Fishman M, Egbert PR. Multiple ocular anomalies associated with maternal LSD ingestion. Arch Ophthalmol 1978; 96: 282-284.

184 Good WV, Ferriero DM, Golabi M, Kobori JA. Abnormalities of the visual system in infants exposed to cocaine. Ophthalmology 1992; 99: 341-346.

185 Bistner S, Rubin L, Aguine G. Development of the bovine eye. Am J Vet Res 1973; 34: 7-12.

186 Chan T, Bowell R, O'Keefe M, Lanigan B. Ocular manifestations in fetal alcohol syndrome. $\mathrm{Br}$ J Ophthalmol 1991; 75: 524-526.

187 Stromland K. Ocular involvement in the fetal alcohol syndrome. Surv Ophthalmol 1987; 31: 277-284.

188 Cook CS, Nowotny AZ, Sulik KK. Fetal alcohol syndrome. Arch Ophthalmol 1987; 105: 1576-1582.

189 Donat JFG. Septo-optic dysplasia in an infant of a diabetic mother. Arch Neurol 1981; 38: 580-591.

190 Kim RY, Hoyt WF, Lessel S, Narahara MH. Superior segmental optic hypoplasia: a sign of maternal diabetes. Arch Ophthalmol 1989; 107: 1312-1315.

191 Patel H, Tze WJ, Crichton JU, McCormick AQ, Robinson GC, Dolman CL. Optic nerve hypoplasia with hypopituitarism. Am J Dis Child 1975; 129: 175-180.

192 Landau K, Bajka JD, Kirchschlager BM. Topless optic disks in children of mothers with type I diabetes mellitus. Am J Ophthalmol 1998; 125: 605-611.

193 Hashimoto M, Ohtsuka K, Nakagawa T, Hoyt WF. Topless optic disk syndrome without maternal diabetes mellitus. Am J Ophthalmol 1999; 128: 111-112.

194 Brodsky M, Glasier C. Optic nerve hypoplasia: clinical significance of associated central nervous system abnormalities on magnetic resonance imaging. Arch Ophthalmol 1993; 111: 66-74.

195 Phillips PH, Spear C, Brodsky MC. Magnetic resonance diagnosis of congenital hypopituitarism in children with optic nerve hypoplasia. J Am Assoc Pediatr Ophthalmol Strabismus 2001; 5: 275-280.

196 Williams J, Brodsky MC, Griebel M, Glasier CM, Caldwell D, Thomas P. Septo-optic dysplasia: the clinical insignificance of an absent septum pellucidum. Dev Med Child Neurol 1993; 35: 490-501.

197 De Morsier G. Études sur les dysraphies crànioencephaliques III. Agénésie du septum lucidum avec malformation du tractus optique. La dysplasie septooptique. Schweitz Arch Neurol Psychiatr 1956; 77: 267-292.

198 Hoyt WF, Kaplan SL, Grumbach MM, Glaser J. Septo-optic dysplasia and pituitary dwarfism. Lancet 1970; i: 93.

199 Benoit-Gonin JJ, David M, Feit JP. La dysplasie septooptique avec déficit en hormone antidiurétique et insuffisance surrénale centrale. Nouv Presse Med 1978; 37: 3327-3331.

200 Billson F, Hopkins IJ. Optic nerve hypoplasia and hypopituitarism. Lancet 1972; i: 905.

201 Brook GD, Sanders MD, Hoare RD. Septo-optic dysplasia. Br Med J 1972; 3: 811-813.

202 Ellenberger C, Runyan TE. Holoprosencephaly with hypoplasia of the optic nerves, dwarfism and agenesis of the septum pellucidum. Am J Ophthalmol 1970; 70: 960-967.

203 Harris RJ, Haas L. Septo-optic dysplasia with growth hormone deficiency (de Morsier syndrome). Arch Dis Child 1972; 47: 973-976.

204 Kaplan SL, Grumbach MM, Hoyt WF. A syndrome of hypopituitary dwarfism, hypoplasia of the optic nerves and malformation of the prosencephalon. Pediatr Res 1970; 4: 480-486.

205 Krause-Brucker W, Gardner DW. Optic nerve hypoplasia associated with absent septum pellucidum and hypopituitarism. Am J Ophthalmol 1980; 89: 113-120.

206 Skarf B, Hoyt CS. Optic nerve hypoplasia in children. Association with anomalies of the endocrine and CNS. Arch Ophthalmol 1984; 102: 62-67.

207 Stanhope R, Preece MA, Brooke CGD. Hypoplastic optic nerves and pituitary dysfunction. Arch Dis Childhood 1984; 59: 111-114.

208 Griffiths P, Hunt S. Specific spatial defect in a child with septo-optic dysplasia. Dev Med Child Neurol 1984; 26: 391-400.

209 Brodsky M. Septo-optic dysplasia: a reappraisal. Semin Ophthalmol 1991; 6: 227-232.

210 Kaufman LM, Miller MT, Mafee MF. Magnetic resonance imaging of pituitary stalk hypoplasia. Arch Ophthalmol 1989; 107: 1485-1490.

211 Zeki S, Hollman A, Dutton G. Neuroradiological features of patients with optic nerve hypoplasia. J Pediatr Ophthalmol Strabismus 1992; 29: 107-112.

212 Hale BR, Rice P. Septo-optic dysplasia: clinical and embryological aspects. Dev Med Child Neurol 1974; 16: 812-820.

213 Jelliger K, Gross H. Congenital telencephalic defects. Neuropaediatrics 1973; 4: 446-452.

214 Kallmann FJ, Shoenfeld WA, Barrera SE. Genetic aspects of primary eunuchoidism. Am J Ment Defic 1943; 48: 203-228.

215 Lightman S. Kallmann's Syndrome. J Roy Soc Med 1988; 81: 315-317.

216 Costin G, Murphree AL. Hypothalamic-pituitary function in children with optic nerve hypoplasia. Am J Dis Child 1985; 139: 249-254.

217 Lambert SR, Hoyt CS, Narahara MH. Optic nerve hypoplasia. Surv Ophthalmol 1987; 32: 1-9.

218 Brodsky MC, Conte FA, Taylor D, Hoyt CS, Mrak RE. Sudden death in septo-optic dysplasia. Report of 5 cases. Arch Ophthalmol 1997; 115: 66-70.

219 Sherlock DA, McNicol LR. Anaesthesia and septo-optic dysplasia. Implications of missed diagnosis in the perioperative period. Anaesthesia 1987; 42: 1302-1305.

220 Sorkin JA, Davis PC, Meacham LR, Parks JS, Drack AV, Lambert SR. Optic nerve hypoplasia: absence of posterior pituitary bright signal on magnetic resonance imaging correlates with diabetes insipidus. (see comments). Am J Ophthalmol 1996; 122: 717-723.

221 Acers TE. Optic nerve hypoplasia: septo-optic-pituitary dysplasia syndrome. Trans Am Ophthalmol Soc 1981; 79: 425-457.

222 Siatkowski RM, Sanchez JC, Andrade R, Alvarez A. The clinical, neuroradiographic, and endocrinologic profile of patients with bilateral optic nerve hypoplasia. Ophthalmology 1997; 104: 493-496.

223 Hanna CE, Mandel SH, LaFranchi SH. Puberty in the syndrome of septo-optic dysplasia. Am J Dis Child 1989; 143: $186-189$.

224 Traggiai C, Stanhope R. Body mass index and hypothalamic morphology on MRI in children with congenital midline cerebral abnormalities. J Pediatr Endocrinol Metab 2004; 17: 219-221. 
225 Traggiai C, Stanhope R. Endocrinopathies associated with midline cerebral and cranial malformations. J Pediatr 2002 140: 252-255.

226 Cagianut B, Theiler K. [On aplasia of the optic nerve (author's transl)]. Albrecht Von Graefes Arch Klin Exp Ophthalmol 1976; 200: 93-98.

227 Recordon E, Griffiths GM. A case of primary bilateral anophthalmia. Br J Ophthalmol 1936; 22: 353-361.

228 Haberland O, Perou M. Primary bilateral anophthalmia. I Neuropathol Exp Neurol 1969; 28: 337-351.

229 Penner H, Schlack HG. Anophthalmia and accompanying malformations (author's transl). Klin Padiatr 1976; 188 320-327.

230 Dell'Osso LF, Williams RW, Jacobs JB, Erchul DM. The congenital and see-saw nystagmus in the prototypical achiasma of canines: comparison to the human achiasmatic prototype. Vision Res 1998; 38: 1629-1641.

231 Dell'Osso LF, Hertle RW, Williams RW, Jacobs JB. A new surgery for congenital nystagmus: effects of tenotomy on an achiasmatic canine and the role of extraocular proprioception. J Am Assoc Pediatr Ophthalmol Strabismus 1999; 3: 166-182.

232 Apkarian P, Bour L, Barth PG. A unique achiasmatic anomaly detected in non-albinos with misrouted retinalfugal projections. Eur J Neurosci 1994; 6: 501-507.

233 Apkarian P, Bour LJ, Barth PG, Wenniger-Prick L, Verbeeten Jr B. Non-decussating retinal-fugal fibre syndrome. An inborn achiasmatic malformation associated with visuotopic misrouting, visual evoked potential ipsilateral asymmetry and nystagmus. Brain 1995; 118 (Part 5): 1195-1216.

234 Meckel JW. Handbuchder pathologischen Anatomie. Carl Heinrich Reclam: Halle, 1812, pp 398-399.

235 Henle J. Handbuch der Nervenlehre des Menschen. Friedreich Vieweg: Braunschweig, 1871, pp 345-348.
236 Vesalius A. De humani corporis fabrica. Caput III. De primo nervorum a cerebro originem. I.Oporini: Basiliae, 1543, pp 324-325.

237 el Gammal T, Brooks B, Harbour R, Kline L, Jacob P. MR of uncommon congenital and vascular lesions of the intracranial visual pathways. Neuroradiology 1990; 32: 488-491.

238 Leitch RJ, Thompson D, Harris CM, Chong K, RussellEggitt I, Kriss A. Achiasmia in a case of midline craniofacial cleft with seesaw nystagmus. $\mathrm{Br} J$ Ophthalmol 1996; 80: 1023-1024.

239 Thompson DA, Kriss A, Chong K, Harris C, Russell-Eggitt I, Shawkat $\mathrm{F}$ et al. Visual-evoked potential evidence of chiasmal hypoplasia. Ophthalmology 1999; 106: 2354-2361.

240 Victor JD, Apkarian P, Hirsch J, Conte MM, Packard M, Relkin NR et al. Visual function and brain organization in non-decussating retinal-fugal fibre syndrome. Cereb Cortex 2000; 10: 2-22.

241 Jansonius NM, van der Vliet TM, Cornelissen FW, Pott JW, Kooijman AC. A girl without a chiasm: electrophysiologic and MRI evidence for the absence of crossing optic nerve fibers in a girl with a congenital nystagmus. J Neuroophthalmol 2001; 21: 26-29.

242 Korff CM, Apkarian P, Bour LJ, Meuli R, Verrey JD, Roulet $P E$. Isolated absence of optic chiasm revealed by congenital nystagmus, MRI and VEPs. Neuropediatrics 2003; 34: 219-223.

243 Alvarez-Bolado G, Schwartz M, Gruss P. Pax2 in Chiasm. Cell Tissue Res 1997; 290: 197-200.

244 Waheed K, Jan W, Calver DM. Aplasia of the optic chiasm and tracts with unifocal polymicrogyria in an otherwise healthy infant. J Pediatr Ophthalmol Strabismus 2002; 39: 187-189.

245 Bowman W. Inaugural Address at the first Meeting of the Society (Ophthalmological Society of the United Kingdom June 23rd 1880). Trans Ophthalmol Soc UK 1881; 1: 1-5. 